\title{
Interaction of Symbiotic Rhizobia and Parasitic Root-Knot Nematodes in Legume Roots: From Molecular Regulation to Field Application
}

\author{
Sofia R. Costa, ${ }^{1}$ Jason Liang Pin $\mathbf{N g},{ }^{2}$ and Ulrike Mathesius ${ }^{2,+}$ \\ ${ }^{1}$ CBMA - Centre of Molecular and Environmental Biology, Department of Biology, University of Minho, Campus de Gualtar, \\ 4710-057 Braga, Portugal \\ ${ }^{2}$ Division of Plant Sciences, Research School of Biology, Australian National University, Canberra ACT 2601, Australia
}

Accepted 19 January 2021.

\begin{abstract}
Legumes form two types of root organs in response to signals from microbes, namely, nodules and root galls. In the field, these interactions occur concurrently and often interact with each other. The outcomes of these interactions vary and can depend on natural variation in rhizobia and nematode populations in the soil as well as abiotic conditions. While rhizobia are symbionts that contribute fixed nitrogen to their hosts, parasitic root-knot nematodes (RKN) cause galls as feeding structures that consume plant resources without a contribution to the plant. Yet, the two interactions share similarities, including rhizosphere signaling, repression of host defense responses, activation of host cell division, and differentiation, nutrient exchange, and alteration of root architecture. Rhizobia activate changes in defense and development through Nod factor signaling, with additional functions of effector proteins and exopolysaccharides. RKN inject large numbers of protein effectors into plant cells that directly suppress immune signaling and manipulate developmental pathways. This review examines the molecular control of legume interactions with rhizobia and RKN to elucidate shared and distinct mechanisms of these root-microbe interactions. Many of the molecular pathways targeted by both organisms overlap, yet recent discoveries have singled out differences in the spatial control of expression of developmental regulators that may have enabled activation of cortical cell division during nodulation in legumes. The interaction of legumes with symbionts and parasites highlights the importance of a comprehensive view of root-microbe interactions for future crop management and breeding strategies.
\end{abstract}

${ }^{\dagger}$ Corresponding author: U. Mathesius; ulrike.mathesius@anu.edu.au

Funding: Work by S. R. Costa was supported by the strategic programme UID/BIA/04050/2019 (POCI-01-0145-FEDER-007569) and the project Handler (POCI-01-0145-FEDER-029283; PTDC ASP-PLA/29283/2017) funded by national funds through the Portuguese Foundation for Science and Technology and by the European Regional Development Fund through the COMPETE2020 Programa Operacional Competitividade e Internacionalização. Work by J. L. P. Ng and U. Mathesius was supported by the Australian Research Council and the Grains Research and Development Corporation through grants IH140100013 and DP190101817.

The author(s) declare no conflict of interest.

(c) (1) $(9)($ Copyright $\odot 2021$ The Author(s). This is an open access article distributed under the CC BY-NC-ND 4.0 International license.
Keywords: defense, infection, nodulation signaling, nodule, nutrient competition, rhizobia, root gall, root-knot nematode

One of the future goals in crop improvement is the facilitation of symbioses that improve nutrient acquisition while reducing pathogenic interactions. This requires an understanding of the similarities and differences of the underlying processes that plants use to respond to symbionts and pathogens. Plants have coevolved with the presence of microorganisms, including diverse species of bacteria, fungi, protozoans, and nematodes. Some of these microorganisms specifically infect plants, in particular, roots, which are exposed to a high abundance of microorganisms in the soil. In specific cases, microorganisms additionally induce the development of new root organs in their host roots, which provide a physical niche as well as facilitating nutrient exchange between host and microorganisms. Here, we compare the interaction of plant hosts with symbiotic rhizobia that induce formation of nitrogen-fixing nodules in legumes and their infection with plant endoparasitic nematodes (root-knot nematodes $[\mathrm{RKN}]$ ) that induce the formation of galls (Fig. 1). Despite the different outcomes - symbiotic or parasitic - both processes encompass signaling in the rhizosphere before the start of the infection, control of plant defense responses to allow invasion, induction of cell division and differentiation by signals from the microorganisms, and the physical invasion of root cells and intensive nutrient exchange. Thus, it has been hypothesized that the rhizobium-legume symbiosis and RKN parasitism share some common regulatory pathways (Bird and Kaloshian 2003; Damiani et al. 2012; Hutangura et al. 1999; Koltai et al. 2001; Mathesius 2003). Both interactions also have important ecological consequences for host plants and plant communities. A summary of the key features of both interactions is shown in Table 1 and details are further described below. The comparison of these symbiotic and parasitic interactions addresses several of the top ten questions in plant-microbe interactions proposed recently (Harris et al. 2020).

Many but not all species of legumes form symbioses with nitrogen-fixing rhizobia, which include many species across several genera of $\alpha$ and $\beta$ proteobacteria (Peix et al. 2015). The symbiosis emerged evolutionarily relatively recently $(<100$ million years ago [MYA]) in a Rosids clade (Doyle 2011). Other nonlegume Rosids that form root nodules with nitrogenfixing symbionts are actinorhizal plants that interact with actinomycetes called Frankia (Santi et al. 2013). It is likely that a single evolutionary event enabled these Rosids to form 
nodule-based symbioses, although it remains unclear what that event was (Griesmann et al. 2018; van Velzen et al. 2019). A likely reason for the acquisition of nitrogen-fixing root nodulation was that, during a time of high atmospheric $\mathrm{CO}_{2}$ concentration, nitrogen-fixing symbioses would have provided additional nitrogen that allowed higher photosynthetic rates to take advantage of increased $\mathrm{CO}_{2}$ (Sprent and James 2007). However, the symbiosis only forms if nitrogen is otherwise unavailable (Streeter 1988). In addition, many species of legumes cannot form the symbiosis, most likely because of a secondary loss of the ability to nodulate (Griesmann et al. 2018; van Velzen et al. 2019).

The host plant initiates the interaction with rhizobia by exudation of mixtures of specific flavonoids that act as chemotactic attractors for rhizobia as well as activating the expression of nodulation genes in a species-specific manner, thus partly determining host range (Liu and Murray 2016). Nodulation genes in rhizobia encode a number of symbiosisrelated proteins, including enzymes necessary for the synthesis of Nod factors and exopolysaccharides. Nod factors are lipochitin oligosaccharides with structures specific for the rhizobial species that synthesize them (Oldroyd and Downie 2008). Nod factors are essential in most, but not all (Giraud et al. 2007) species of rhizobia to initiate and maintain the nodulation program. Exopolysaccharides are surface molecules of rhizobia that, again, have species-specific structures. Their functions have primarily been linked to the depression of host defense responses. Exopolysaccharide mutants typically infect the host poorly and form white, ineffective nodules (Jones et al. 2008). The Nod factors are recognized by specific Nod factor receptors on their legume host and are necessary for both the infection process and the concomitant
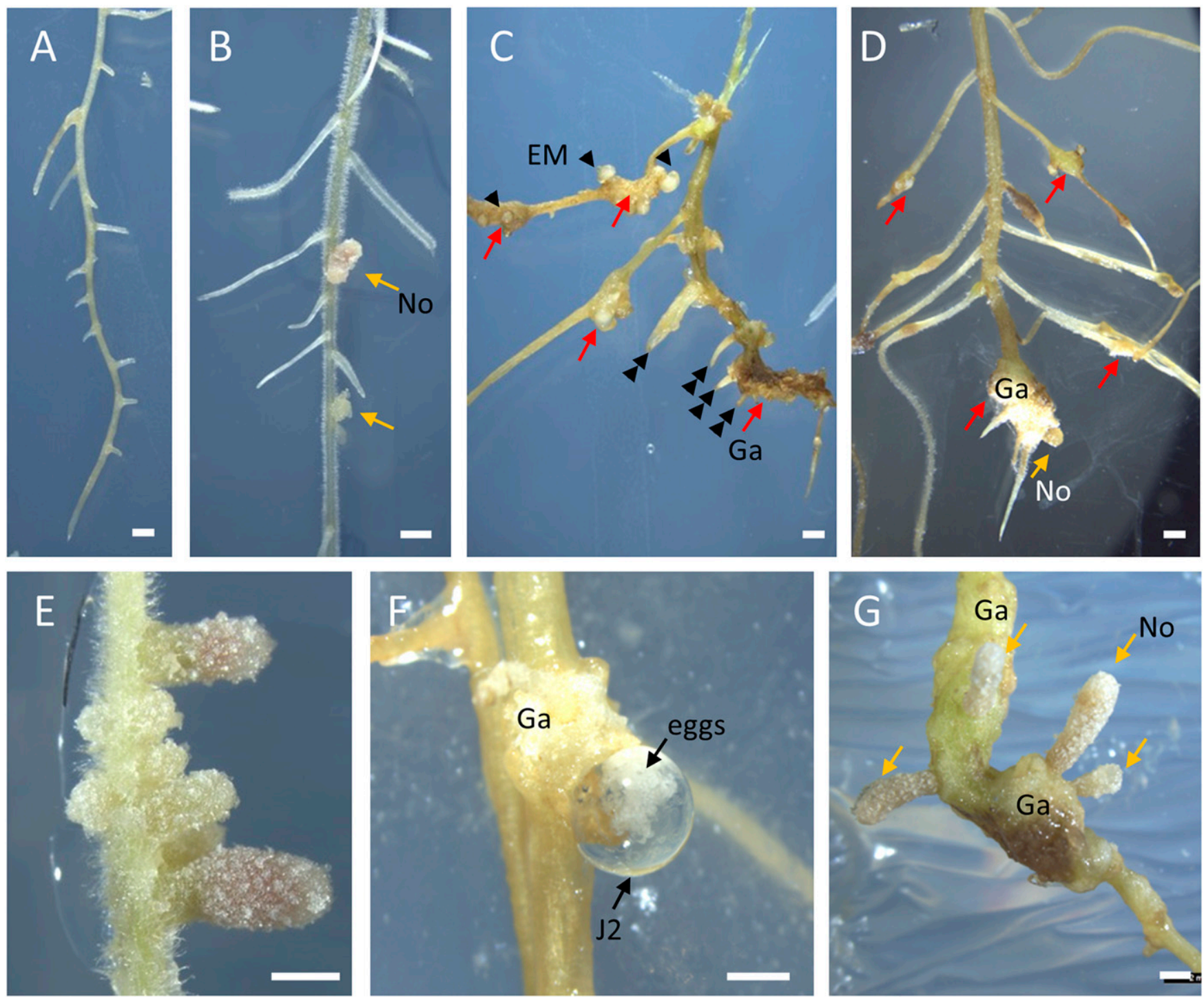

Fig. 1. Phenotypes of Medicago truncatula roots infected with rhizobia and root-knot nematodes (RKN). All plants were wild-type Medicago truncatula grown under sterile conditions on nutrient agar containing $0.5 \mathrm{mM} \mathrm{KNO}_{3}$ and infected with either Sinorhizobium meliloti 1022, Meloidogyne javanica, or both. A, Uninfected root. B, Root infected with S. meliloti 10 days after inoculation, having formed several nodules (No, orange arrows) along the root. C, Root infected with M. javanica that has induced multiple galls (Ga, red arrows), some of them with egg masses (EM) visibly protruding from the surface of the gall at 6 weeks after inoculation. Note that galls are often associated with multiple short lateral roots forming near the gall (double arrow heads). Notable is also the distortion of the whole root system as a result of galling. D, Root inoculated with S. meliloti and M. javanica at the same time. The root has formed galls (Ga, red arrows) and a nodule (No, orange arrow) on top of a gall. E, Closeup of nodules forming on the root, two mature nodules contain pink leghemoglobin, while the younger nodules do not. F, Mature gall with a protruding egg mass containing many eggs and freshly hatched juvenile nematodes (J2 stages). G, Root infected with rhizobia and RKN showing a close-up of galls on which mature nodules (orange arrows) have formed. Magnification bars represent $2 \mathrm{~mm}$. 
initiation of cell divisions in the pericycle and cortex that lead to the development of a root nodule (Oldroyd and Downie 2008). In many legumes, rhizobia infect through infection threads traversing root hairs and cortical cells until rhizobia are released into dividing cortical cells (Murray 2011). In other legumes, rhizobia can infect intercellularly through 'crack entry' between epidermal and cortical cells, which may have been the original infection method before infection thread invasion (Masson-Boivin et al. 2009; Sprent 2007). Rhizobia are then endocytosed into the dividing cortical cells and remain surrounded by the plant plasma membrane, now called the symbiosome membrane, that encapsulates one or several bacteria (Oldroyd and Downie 2008). Rhizobia differentiate into bacteroids that fix atmospheric nitrogen into ammonia, which is converted into amino acids and exported to the host. In exchange, rhizobia receive carbon sources from the host phloem in the form of sucrose, which is then converted to organic acids (Udvardi and Poole 2013). Rhizobia are maintained inside nodules, but the host also has the ability to 'sanction' nodules colonized by rhizobia that fix nitrogen poorly or not at all (Kiers and Denison 2008). Legume hosts also control the bacterial composition inside nodules with a large number of peptides that can control terminal differentiation of rhizobia inside nodules (Van de Velde et al. 2010). Nodules later senesce, and some of the bacteria contained inside nodules can be released into the soil. Decomposition of nitrogen-rich legume tissue significantly increases soil nitrogen content and legumes have been used for millennia to improve plant nutrition as intercrops and rotational crops in combination with nonlegumes.

Table 1. Comparison of plant interactions with symbiotic rhizobia and root-knot nematodes (RKN)

\begin{tabular}{lc}
\hline Feature & Legume-rhizobia symbiosis \\
\hline Invading microorganisms & Several genera with many species and strains \\
of $\alpha$ and $\beta$ proteobacteria & Can be free-living or symbiotic; recruited \\
Lifestyle of invading organism & from the soil for each new nodule formed \\
& on host \\
& \\
Evolutionary origin & 60 to 100 million years ago (MYA) \\
Host range & Specific species of legumes, but some \\
& variation in breadth of host range between \\
& species of rhizobia \\
Microbial signals initiating infection & Species-specific Nod factors with additional \\
& functions of exopolysaccharides and \\
protein effectors necessary to initiate an & infection thread or intercellular invasion \\
Microbial signals controlling defense & Nod factors, exopolysaccharides, quorum- \\
responses & sensing signals, nodule outer proteins
\end{tabular}

Microbial signals initiating organ development

Physical niche of invading organism

Host genes controlling interaction

Nutrient exchange

Developmental changes

Effect on host

Effect on each other

Ecological consequences

Management options to improved outcome for plant host or ecosystem
Nod factors that target cell cycle and hormone signaling; extracellular perception of Nod factors alters host gene expression

Inside plant cells in the center of the nodule, bounded by plant symbiosome membranes, similar to an organelle

Essential nodulation genes for Nod factor perception and signal transduction Autoregulation genes

Nodule-specific peptides

Carbon (sucrose) import into nodule via SWEET transporters, carbon supply to bacteroids via organic acids; ammonium export from bacteroids to host cells; transfer cells present in nodule vascular tissue

Initial pericycle followed by (mainly) cortical cell divisions, invasion of cortical cells, development of organized vascular bundles in the nodule; endoreduplication in nodule zone II

Improved $\mathrm{N}$ nutrition, changes to root architecture

Nodulation often, but not always, protects plant from nematode infection

Improved host success in environment; improved nutrition of neighboring or subsequently grown plants

Inoculation of legumes with rhizobia; selection of effective strains; reducing $\mathrm{N}$ fertilizer to encourage symbiosis; reducing abiotic stress
Plant-RKN parasitism

Parasitic RKN (roundworms); >90 species of the genus Meloidogyne

Obligate endoparasite, only the juvenile stage lives outside the root for short periods of time; invading root from soil for every new gall formed on host

likely >200 MYA

Wide host range of virtually all species of monocots and dicots, but some variation in host range between species of RKN

Physical invasion by intercellular movement of nematodes

Mixture of nematode effectors, e.g., ascarosides (similar to quorum-sensing signals), specific effector proteins injected into plant cells

Mixture of many nematode effectors (hormones, peptides, and proteins), also targeting hormone and cell cycle signaling; extra- and intracellular perception of effectors injected into plants

Extracellular; female RKN become sedentary in the vascular cylinder between cells and only pierce giant cells with their stylet.

Resistance genes; generally lack of specific host genes that are exclusively for nematode defense or gall formation; most necessary genes are also necessary for host function

Sucrose import into giant cells via SWEET and SUC transporters; uptake of amino acids and other nutrients from phloem and xylem; giant cells have transfer cell characteristics and are located adjacent to phloem and xylem

Formation of giant cells by acytokinetic mitoses and endoreduplication from vascular parenchyma initials; mitosis in (mainly) pericycle and some cortical cell divisions accompany giant cell expansion Nutrient limitation, stunted growth, misdeveloped root system, reduced water uptake

Nematode parasitism often, but not always, reduces nodulation

Reduced host success in environment; reduced resistance to other pathogens

Plant rotation, increased host diversity, host resistance; encouraging beneficial microbes in soil; reducing abiotic stress 
In contrast to the beneficial effects of rhizobia on their host plants (Herridge et al. 2008), parasitic nematodes cause substantial damage to crops, estimated at US\$100 billion annually, worldwide (Nicol et al. 2011). The phylum Nematoda is large and diverse, and plant parasitism is thought to have evolved several times independently in different nematode phyla, most likely from fungal or root-feeding nematodes that gradually evolved a sedentary endoparasitic lifestyle (Holterman et al. 2009). RKN belong to the order Tylenchida and most likely originated more than 200 MYA, although no fossil evidence is available to substantiate that estimate (Baldwin et al. 2004).

While ectoparasitic nematodes cause extensive physical damage to roots by penetrating and ingesting roots, endoparasitic nematodes, including $\mathrm{RKN}$, are thought to be the most destructive plant parasites (Jones et al. 2013). Endoparasitic nematodes require a plant host to complete their life cycle and initiate the formation of special feeding sites in their hosts, in which they reside for most of their life, ingesting plant cell content (Williamson and Gleason 2003). This is in contrast to
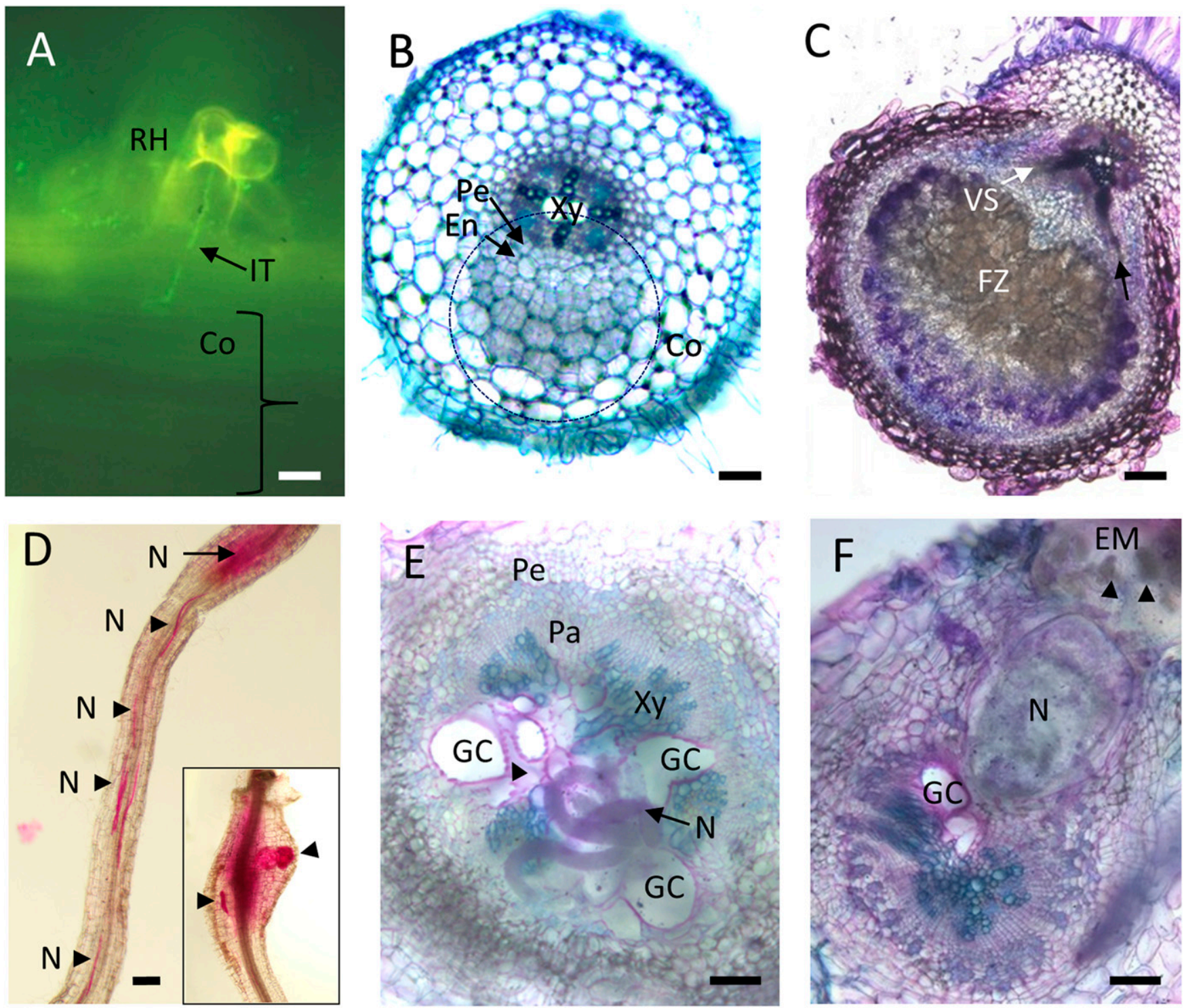

Fig. 2. Developmental changes in Medicago truncatula roots infected with rhizobia and root-knot nematodes. A, Infection thread (IT) elongating through a curled root hair $(\mathrm{RH})$ into the underlying cortex $(\mathrm{Co}) 2$ days after inoculation with Sinorhizobium meliloti. Rhizobia constitutively expressed green fluorescent protein (GFP) and can be seen as a fine green line inside the infection thread. Photo was taken under blue excitation to visualize GFP, B, Young nodule primordium (circled) 3 days after inoculation, characterized by cell divisions (arrows) in the pericycle (Pe), endodermis (En), and, mainly, in the cortical cell layers (Co). The xylem (Xy) shows a symmetrical pattern in the center of the vascular tissue. C, Infected nodule 10 days after inoculation. The nodule shows the fixation zone (FZ) in which rhizobia are localized inside bacteroids in the center of the nodule. The vascular strands (VS, arrows) branch from the main root to the periphery of the nodule to supply nutrients to the nodule and to export fixed nitrogen. D, Root tip showing infecting J2s shortly after inoculation with Meloidogyne javanica. Nematodes (N, pink) invade the root just behind the tip and then move upward through the vascular tissue by intercellular movement until they form a feeding site (arrow). The insert shows a more mature feeding site with stationary young (left) and a more mature (right) female with a developing egg mass inside the root. E, Cross section through a developing gall 1 week after inoculation. The gall harbors the invading nematode ( $\mathrm{N}$, arrow) that has initiated a number of giant cells (GC). Note the cell wall ingrowth visible on the GC cell walls (pink, arrowhead). The gall is characterized by dividing cells in the pericycle $(\mathrm{Pe})$ and vascular parenchyma $(\mathrm{Pa})$. F, Mature gall at 4 weeks after inoculation showing a mature, oval-shaped female nematode (N) that has produced an egg mass (EM) containing several eggs (arrow heads). The female feeds from the giant cells (GC). Magnification bars represent $30 \mu \mathrm{m}$ in A, $100 \mu \mathrm{m}$ in B, E, and F, $200 \mu \mathrm{m}$ in C, and $500 \mu \mathrm{m}$ in D. Sections in B, C, E, and F were stained with toluidine blue O and nematodes in D were stained with acid fuchsin. 
rhizobia, which do not require a host for their survival in the soil.

As with rhizobia, the interaction between plants and RKN starts in the soil with the attraction of nematodes to host root exudates near the root tips (Čepulyte et al. 2018; Perry 1997). Several attractants have been identified, including $\mathrm{CO}_{2}, \mathrm{pH}$ gradients, salicylic acid, methyl jasmonate, ethephon and lauric acid, but it is so far unknown what determines the host range of RKN (Sikder and Vestergård 2020). The juvenile nematodes (J2s) then enter the root just behind the root tip and move intercellularly into the vascular tissue, where they reverse direction and move away from the root tip for a short distance (Williamson and Gleason 2003) (Fig. 2D). The inability of J2s to penetrate the Casparian strip in the endodermis is a likely reason why they infect the tip, where the endodermis is not suberised (Holbein et al. 2019). In the vascular tissue, RKN locate target feeding cells, typically vascular parenchyma cells, into which they inject a large number of effectors through a stylet (Williamson and Gleason 2003). These effectors are mixtures of proteins and peptides with multiple functions in controlling cell-wall modifications, host defense responses, and initiating feeding site formation (Truong et al. 2015). Effectors of RKN convert vascular parenchyma cells into so-called 'giant cells,' from which female nematodes feed directly by ingesting plant cytoplasm. The giant cells are embedded inside a gall-like structure that forms on the root by additional divisions in pericycle and cortical cells (Jones 1981). The female nematode matures inside the gall, laying eggs inside a gel-like matrix called the egg mass, often containing hundreds of eggs each (Fig. 1F). Thousands of galls can form on a single plant, crippling the growth of the root system and interrupting the vascular tissue. This leads to reduced plant yield with often difficult-todiagnose aboveground symptoms (Moens et al. 2009). The interaction between RKN and host plants is complex, and crop damage in the field is currently hampered by the absence of safe and sustainable control methods. Little durable resistance to RKN has been found, and nematode populations are often able to overcome resistance in a few generations (CastagnoneSereno et al. 2013).

While nitrogen-fixing nodules are only formed in legumes, plant parasitic nematodes have a wide host range, which encompasses most monocots and dicots and also includes legumes (Moens et al. 2009). Legumes can therefore be concurrently infected by both rhizobia and plant parasitic nematodes. This can have consequences for symbiosis and parasitism alike. Here, we focus on aspects of root-rhizobia and RKN interactions that explain their interactions and point to possible breeding or management strategies to optimize outcomes for the plant host.

\section{INTERACTIONS BETWEEN RHIZOBIA AND PLANT PARASITIC NEMATODES ON THE SAME HOST}

Most legumes can be infected by various species of RKN but only specific species of rhizobia, although this can include multiple strains that vary in symbiotic properties, including effective nitrogen fixation. In the field, concurrent infection with both rhizobia and RKN is frequent as both groups of microorganisms are widely distributed in soils around the world. It can be expected that adaptations of plants to parasites could affect their infection by mutualists and vice versa. Many studies have been conducted to test the interactions of rhizobia and RKN on the same host. The research community's interest in establishing whether nodulation by rhizobia and galling by nematodes are balanced by the plant has been mainly driven by agronomy, focusing on legume performance as crops (Table 2). Accordingly, most published studies describe the results of pot trials, lasting 2 to 3 months, and targeted pulses, such as chickpea, cowpea, and mung bean, or on cover crops such as hairy vetch. A large proportion did not gather data on the effects of the concomitant inoculation of rhizobia and RKN on nematode galling, as the objective was to find conditions to alleviate any (negative) nematode effects on nodulation.

An overall trend becomes apparent for reduced nodule numbers and often reduced gall numbers when both rhizobia and RKN were inoculated, but this is not a universal effect (Table 2). In fact, both neutral and positive effects on one or both galling and nodulation have been reported besides negative effects, suggesting an idiosyncratic relation. It also needs to be kept in mind that the reported nodule and gall numbers do not necessarily reflect similar changes in nitrogen fixation or nematode infection numbers and, thus, must be viewed with some caution. The outcomes of the RKN-plant-rhizobia interaction can be affected by soil substrate used (Siddiqui et al. 1999), duration of the experiment (Desaeger et al. 2005), and nematode population density (Chahal and Chahal 1988; Desaeger et al. 2005). Interestingly, nodulation and galling are dependent on the identity of the interacting partners, including at the subspecific level, as assessed for, e.g., different RKN genotypes (Wood et al. 2018), plant mutants (Costa et al. 2020), and rhizobial strains (Duponnois et al. 1999). Apart from identity, based on information in Table 2, it seems plausible that the diversity of rhizobia can also affect the overall effect of concomitant inoculations, as indigenous rhizobia and those originating from crushed nodules often nodulate irrespectively of nematode inoculation. However, this would need to be confirmed by conducting controlled experiments with planned combinations of rhizobial strains.

\section{GENETIC BASIS FOR RHIZOBIA-NEMATODE INTERACTIONS ON LEGUME HOSTS}

The mutual interactions between rhizobia and RKN might be based on the molecular and biochemical changes occurring in or outside the host during the interactions. From an evolutionary perspective, it is likely that root-nematode interactions evolved earlier (>200 MYA) than rhizobium-legume symbioses (<100 MYA). Therefore, host genes regulating parasitism would have likely been in place at the time rhizobia started to form a symbiosis with legume hosts. At the time of the emergence of nodulating symbioses, legume traits that had evolved to limit parasitism may have affected mutualism. Since then, those traits could have further evolved to balance interactions with both parasites and mutualists. The interactions between rhizobia and nematodes on the same host are likely a result of overlapping signals and responses playing a role in root nodule symbiosis and nematode parasitism.

There is evidence that host genes are involved in mutual interactions of RKN and rhizobia on legume hosts. The controlled assays, conducted by Wood et al. (2018), inoculating 40 different but related Meloidogyne hapla genotypes and a wellcharacterized rhizobium strain on a large number of different genotypes of the model legume Medicago truncatula points to a plant-mediated trade-off effect, i.e., the capacity to establish mutualistic associations with rhizobia seems to be genetically linked to attractiveness of antagonist nematodes. Accordingly, the authors found a positive correlation between numbers of galls formed and the numbers of nodules (nodules being quantified in the absence of RKN). This finding is corroborated by the inverse proportion of nodules and galls formed in cowpea (Izuogu et al. 2019). The genetic basis of this observation is currently not known. 
There is also evidence that nodulation signaling is required for the protective effect of rhizobia on RKN infection under controlled conditions. A study using Medicago truncatula found that the reduction in gall number caused by concurrent infection with Meloidogyne javanica, compared with rhizobia- only infected plants, was observed in wild-type plants but not in nonnodulating mutants (Costa et al. 2020).

This prompts a question about the biochemical and molecular similarities between the interactions of legumes with rhizobia and RKN that could explain the above observations.

Table 2. Effects of concomitant inoculation of root-knot nematodes and rhizobia on galling and nodulation of legumes

\begin{tabular}{|c|c|c|c|c|c|c|}
\hline \multirow[b]{2}{*}{ Plant species } & \multirow[b]{2}{*}{$\begin{array}{l}\text { Common } \\
\text { name }\end{array}$} & \multirow[b]{2}{*}{$\begin{array}{l}\text { Nematode } \\
\text { species }\end{array}$} & \multirow[b]{2}{*}{ Rhizobia species } & \multicolumn{2}{|c|}{ Effect of concomitant inoculation on } & \multirow[b]{2}{*}{ Reference } \\
\hline & & & & $\begin{array}{c}\text { Gall } \\
\text { numbers }\end{array}$ & Nodule numbers & \\
\hline $\begin{array}{l}\text { Faidherbia } \\
\text { albida }\end{array}$ & Acacia & $\begin{array}{l}\text { Meloidogyne } \\
\text { javanica }\end{array}$ & Indigenous & $\mathrm{N} / \mathrm{A}$ & Increased & Ruponnois et al. 1999 \\
\hline Glycine max & Soybean & $\begin{array}{l}\text { M. hapla, } M \text {. } \\
\text { incognita }\end{array}$ & $\begin{array}{l}\text { Commercial Rhizobium } \\
\text { japonicum }\end{array}$ & $\mathrm{N} / \mathrm{A}$ & Increased & $\begin{array}{l}\text { Hussey and Barker } \\
1976\end{array}$ \\
\hline Acacia hiliana & Acacia & M. javanica & Indigenous & N/A & Neutral & Duponnois et al. 1997 \\
\hline A. lysiphloia & Acacia & M. javanica & Indigenous & N/A & Neutral & Duponnois et al. 1997 \\
\hline A. raddiana & Acacia & M. javanica & Indigenous & N/A & Neutral & Ruponnois et al. 1999 \\
\hline $\begin{array}{l}\text { A. sclero- } \\
\text { sperma }\end{array}$ & Acacia & M. javanica & Indigenous & N/A & Neutral & Duponnois et al. 1997 \\
\hline A. senegal & Acacia & M. javanica & Indigenous & N/A & Neutral & Ruponnois et al. 1999 \\
\hline A. trachycarpa & Acacia & M. javanica & Indigenous & N/A & Neutral & Duponnois et al. 1997 \\
\hline A. tumida & Acacia & M. javanica & Indigenous & N/A & Neutral & Duponnois et al. 1997 \\
\hline Cicer arietinum & Chickpea & M. incognita & Rhizobium sp. chickpea strain & Reduced & Neutral & Khan et al. 2018 \\
\hline Cicer arietinum & Chickpea & M. incognita & Efficient Rhizobium spp. strain & N/A & $\begin{array}{l}\text { Neutral, reduced at high } \\
\text { nematode inoculum }\end{array}$ & $\begin{array}{l}\text { Chahal and Chahal } \\
1998\end{array}$ \\
\hline Cajanus cajan & Pigeon pea & M. incognita & Indigenous & N/A & $\begin{array}{l}\text { Neutral, reduced at high } \\
\text { nematode inoculum }\end{array}$ & Anver and Alam 1999 \\
\hline $\begin{array}{l}\text { Medicago } \\
\text { truncatula }\end{array}$ & $\begin{array}{l}\text { Barrel } \\
\text { medic }\end{array}$ & M. hapla & Effective Ensifer meliloti strain & N/A & $\begin{array}{l}\text { Neutral, reduced at high } \\
\text { nematode inoculum }\end{array}$ & Wood et al. 2018 \\
\hline $\begin{array}{l}\text { Vigna } \\
\text { unguiculata }\end{array}$ & Cowpea & M. incognita & Indigenous & N/A & $\begin{array}{l}\text { Reduced, neutral for one plant } \\
\text { cultivar }\end{array}$ & Izuogu et al. 2019 \\
\hline $\begin{array}{l}\text { Vigna } \\
\text { unguiculata }\end{array}$ & Cowpea & M. incognita & Bradyrhizobium japonicum & $\mathrm{N} / \mathrm{A}$ & Reduced & $\begin{array}{l}\text { Mashela and Pofu } \\
2012\end{array}$ \\
\hline $\begin{array}{l}\text { Vigna } \\
\text { unguiculata }\end{array}$ & Cowpea & M. incognita & Rhizobium leguminosarum strain & N/A & Reduced & Ali et al. 1981 \\
\hline $\begin{array}{l}\text { Vigna } \\
\text { unguiculata }\end{array}$ & Cowpea & M. incognita & Commercial cowpea strain & N/A & Reduced & Khan and Khan 1996 \\
\hline Vicia faba & Broad bean & M. javanica & $\begin{array}{l}\text { Rhizobium spp. (ground broad } \\
\text { bean nodules }\end{array}$ & Increased & Reduced & $\begin{array}{l}\text { El-Bahrawy and } \\
\text { Salem } 1989\end{array}$ \\
\hline Vicia villosa & Hairy vetch & $\begin{array}{l}\text { M. hapla, } M \text {. } \\
\text { javanica }\end{array}$ & Rhizobium leguminosarum & N/A & Reduced & $\begin{array}{l}\text { Malek and Jenkins } \\
1967\end{array}$ \\
\hline Vigna radiata & Mung bean & M. incognita & Commercial mung bean strain & N/A & Reduced & Khan et al. 2002 \\
\hline C. arietinum & Chickpea & M. incognita & Commercial chickpea strain & Reduced & Reduced & Siddiqui et al. 2013 \\
\hline C. arietinum & Chickpea & M. incognita & Commercial chickpea strain & Reduced & Reduced & $\begin{array}{l}\text { Siddiqui and Akhtar } \\
2009\end{array}$ \\
\hline C. arietinum & Chickpea & M. incognita & Commercial chickpea strain & Reduced & Reduced & $\begin{array}{l}\text { Akhtar and Siddiqui } \\
2008\end{array}$ \\
\hline C. arietinum & Chickpea & M. incognita & Commercial chickpea strain & Reduced & Reduced & $\begin{array}{l}\text { Siddiqui and } \\
\text { Mahmood } 2001\end{array}$ \\
\hline C. arietinum & Chickpea & M. incognita & Commercial chickpea strain & Reduced & Reduced & $\begin{array}{l}\text { Siddiqui and Husain } \\
1992\end{array}$ \\
\hline C. cajan & Pigeon pea & M. javanica & Commercial pigeon pea strain & Neutral & Reduced & Khan and Salam 1990 \\
\hline C. cajan & Pigeon pea & M. incognita & Rhizobium sp. pigeon pea strain & Reduced & Reduced & Khan et al. 2018 \\
\hline Glycine max & Soybean & M. incognita & $\begin{array}{l}\text { Rhizobium leguminosarum } 2 \\
\text { strains }\end{array}$ & Reduced & Reduced & Ahmed et al. 2016 \\
\hline Lens culinaris & Lentil & M. incognita & Commercial lentil strain & Reduced & Reduced & Fazal et al. 1992 \\
\hline Lens culinaris & Lentil & M. javanica & Commercial lentil strain & Reduced & Reduced & Siddiqui et al. 2007 \\
\hline $\begin{array}{l}\text { Medicago } \\
\text { sativa }\end{array}$ & Alfalfa & M. javanica & Rhizobium leguminosarum & Reduced & Reduced & Nigh 1966 \\
\hline Pisum sativum & Pea & M. incognita & Rhizobium sp. pea strain & Reduced & Reduced & $\begin{array}{l}\text { Sharma and Tiagi } \\
1990\end{array}$ \\
\hline Vicia faba & Broad bean & M. incognita & $\begin{array}{l}\text { Rhizobium leguminosarum in } \\
\text { bio-fertilizer }\end{array}$ & Reduced & Reduced & El-Shafeey et al. 2019 \\
\hline Vigna radiata & Mung bean & M. incognita & Rhizobium sp. mung bean strain & Neutral & Reduced & $\begin{array}{l}\text { Hussaini and Seshadri } \\
1975\end{array}$ \\
\hline Vigna radiata & Mung bean & M. incognita & Rhizobium sp. mung bean strain & Reduced & Reduced & Khan et al. 2018 \\
\hline Vigna radiata & Mung bean & M. incognita & Efficient Rhizobium sp. strain & Neutral & Reduced & $\begin{array}{l}\text { Chahal and Chahal } \\
1988\end{array}$ \\
\hline Vigna radiata & Mung bean & M. javanica & Mix of seven strains & Reduced & Reduced & Bopaiah et al. 1976 \\
\hline $\begin{array}{l}\text { Vigna } \\
\text { unguiculata }\end{array}$ & Cowpea & M. incognita & Rhizobium (spp.?) & Reduced & Reduced & $\begin{array}{l}\text { Sharma and Sethi } \\
1976\end{array}$ \\
\hline $\begin{array}{l}\text { Vigna } \\
\text { unguiculata }\end{array}$ & Cowpea & M. incognita & Commercial cowpea strain & Reduced & Reduced & $\begin{array}{l}\text { Khan and Husain } \\
1988\end{array}$ \\
\hline
\end{tabular}


Hypothetically, the interactions of RKN and rhizobia on a legume root system could be explained by multiple factors that could depend on plant and microbial genetic factors. i) Both organisms could interact directly. ii) Rhizosphere signals produced by RKN or rhizobia could affect both organisms in various ways, and, conversely, rhizobia and RKN could both have effects on root exudates that directly or indirectly affect each organism in the rhizosphere. iii) Infection with either rhizobia or RKN affects host defense responses with indirect effects on the other organism. iv) Both organisms trigger overlapping changes in developmental pathways required for nodule and gall formation. v) Established nodules and galls could compete for nutrients supplied by the host. vi) Formation of nodules and galls modulates root architecture traits that could indirectly affect the interactions. Below, we evaluate studies that have provided evidence for any of the above hypotheses. Because of the extensive nature of the topic, we apologize to authors whose work could not be cited here.

\section{DIRECT INTERACTIONS OF RHIZOBIA AND NEMATODES}

RKN eggs are laid in an egg mass on the surface of the root, where infective juveniles hatch from the eggs. Hatching of Meloidogyne incognita was inhibited in the presence of different species of rhizobia or their culture filtrates (Khan et al. 2018), suggesting that (so far unidentified) metabolites from rhizobia might have a direct effect on viable nematode numbers in the soil. Rhizobia (and many other species of soil bacteria) can also be present on the surface of nematodes moving to the root and can, thus, be carried toward a host root much faster than through their own movement (Knox et al. 2004; Topalović et al. 2020).

Nematodes and rhizobia can interact after galls and nodules are formed on the root, hijacking each other's structures within the plant, seemingly without affecting their function. Nodules can be formed on galls (Taha and Kassab 1980; Taha and Raski 1969) (Fig. 1G), and galls can be formed on nodules. These are functional galls that support the nematode throughout its developmental cycle and reproduction (Desaeger et al. 2005; Sharma and Sethi 1976; Vovlas et al. 2015).

Infective RKN juveniles do not infect the root uniformly but can display preference for nodules (Taha and Raski 1969). It is possible that RKN target nodules because of their high export of amino acids that may benefit RKN nutrition. Contrary to other plant-parasitic nematodes, RKN have the ability to penetrate the nodule peripheral xylary ring (Barker and Hussey 1976); they then proceed to initiate giant cells, establishing permanent feeding sites in the nodule vascular bundles (Barker and Hussey 1976; Taha and Raski 1969; Vovlas et al. 2015). Although nodule vascular bundles become structurally altered, with corresponding enlargement and disorganization of the nodule cortex (Vovlas et al. 2015), bacteroids are not disrupted, even though they do not develop next to the nematodes (Ali et al. 1981; Barker and Hussey 1976).

Earlier studies suggested nodule function was unaffected by RKN infection (Taha and Raski 1969), but nitrogen fixation can be reduced, possibly through reduced synthesis of nitrogenase and leghemoglobin (Ali et al. 1981; Chahal and Chahal 1988). Nematode-infected nodules are also known to senesce more rapidly (Ali et al. 1981; Barker and Hussey 1976; Taha and Raski 1969).

\section{INTERACTION OF RHIZOBIA AND PARASITIC NEMATODES THROUGH RHIZOSPHERE SIGNALING}

Preceding infection of the root, both rhizobia and RKN communicate with each other through cell-to-cell communication, using diffusible signals that modulate the behaviors of the emitting microorganism as well as defense responses in the plant. Intriguingly, while the structures of the classes of communication signals are different, in both cases the signals contain variable length acyl side chains mediating specificity.

Nematode behaviors, like directed movement and aggregation in the rhizosphere, are controlled by pheromone-like molecules exchanged between nematodes. Ascarosides are small molecules involved in nematode signaling that are widely conserved across phylum Nematoda, having been detected in several genera of free-living, plant- and animal-parasitic nematodes (Choe et al. 2012; Manosalva et al. 2015). These nematode-specific molecules are glycosides of the ascarylose sugar, with a derived fatty acid chain of variable length, produced by peroxisomal $\beta$-oxidation from longer-chained precursors (Butcher et al. 2009). This combination of a sugar with a variable length fatty acid is similar to the structure of Nod factors, which are composed of a short oligosaccharide (three to five units of $\mathrm{N}$-acetyl glucosamine) bound to a fatty acid of variable length and saturation pattern that signals specificity in the rhizobium-legume symbiosis (Fig. 3).

Although the first isolated and described ascaroside from Caenorhabditis elegans medium was a nematode-excreted dauer-inducing pheromone (Jeong et al. 2005), more than 200 ascarosides have now been reported from several genera that elicit changes in nematode behavior or physiology (von Reuss 2018). The length of the fatty-acid chain as well as a range of modifications of both the ascarylose sugar and the fatty acid chain introduced by primary metabolism can affect the function of these molecules dramatically, so their biosynthesis is thought to be highly modular, yielding a vast range of molecules with different functions (Hollister et al. 2013; von Reuss 2018; von Reuss et al. 2012). Ascaroside blends are produced constitutively and excreted in a species-specific manner (Choe et al. 2012), with composition varying according to life stage, nutritional or metabolic status, and other environmental cues (Kaplan et al. 2012; Zhang et al. 2016). When exposed to different environmental conditions, nematodes can tailor existing ascarosides to different forms, eliciting correspondingly different behaviors (e.g., shifting from aggregation to dispersal) by modification of the fatty acid chains without having to synthesize ascarosides de novo (Zhou et al. 2018).

Having been excreted by the nematodes, these pheromones are publicly broadcast in the rhizosphere and can be perceivedand reacted upon-by both nematodes and other organisms (Diaz et al. 2014; Hartley et al. 2019). Importantly, ascarosides produced by plant-parasitic nematodes can be detected by their plant hosts (Klessig et al. 2019; Manohar et al. 2020; Manosalva et al. 2015). Plant-parasitic nematode species Heterodera glycines, Meloidogyne incognita, M. javanica, M. hapla, and Pratylenchus brachyurus all produce blends of ascarosides, of which ascr\#18 is dominant. This ascaroside is recognized by plants, triggering pattern-mediated immunity with activation of mitogen-activated protein kinases and salicylate and jasmonate (JA) defense pathways but not ethylene or auxin signaling pathways. Upon application of ascr\#18 as a root-dip treatment, Arabidopsis, tomato, potato, and barley plants become resistant to nematode infection; further, this broad defense also reduced attack of other plant pathogens at small, ecologically relevant concentrations (Manosalva et al. 2015). Later studies demonstrated similar increased defense of the staple food crops maize, rice, soybean, and wheat against a wide range of pathogens of viral, bacterial, fungal, oomycete, and nematode origin when plants were treated with ascr\#18 (Klessig et al. 2019). The ascaroside is taken up by the plant and transported through unknown processes to be metabolized into derivatives varying in 
fatty-acid side chain length (ascr\#1, ascr\#9, and ascr\#10) by plant-based peroxisomal $\beta$-oxidation. In Arabidopsis, acyl CoA enzymes ACX1 and ACX5 were found to be active in the ascaroside metabolism, and they are also involved in JA and auxin biosynthesis in the plants. Contrary to the attractant effects of ascr\#18 in the RKN $M$. incognita, ascr\#9 and, particularly, a 10:1 proportion of ascr\#9 and ascr\#18 is strongly repellent of the nematodes. In summary, $M$. incognita-excreted ascarosides that attract infective juveniles, elicit incompatible interactions with plants via pattern-triggered immunity and, through metabolism by the plant, are altered into ascarosides with repellent effects on the nematodes (Manohar et al. 2020).

Research is lacking on the effects of ascarosides and particularly of ascr\#18 in plant-rhizobia interactions, and it is unclear whether rhizobia infection would be affected by the pattern-triggered immunity response elicited by ascarosides. While roots can differentiate perception of rhizobia from microbe-associated molecular pattern (MAMP)-triggered plant defense (Tóth and Stacey 2015), some of the general defense responses triggered by ascr\#18, e.g., activation of JA responses, could modulate nodulation signaling (Sun et al. 2006). However, modulation of internal JA concentrations did not influence nodule numbers (Zdyb et al. 2011). In addition, it is unclear whether rhizobia can detect, respond to, or metabolize ascarosides themselves and, to our knowledge, this has not been tested.
Similar to the communication of nematodes by ascarosides, rhizobia and other bacteria communicate with each other and across species with quorum-sensing molecules. Gram-negative bacteria, including rhizobia, use acyl homoserine lactones (AHLs) to change certain behaviors depending on population density. These behaviors are important in rhizosphere colonization and plant-bacterial interactions and include swarming, motility, chemotaxis, production of certain enzymes, and symbiotic nitrogen fixation (Hartmann et al. 2014; SanchezContreras et al. 2007). AHLs with different side chains give these signals specificity, with certain bacterial species producing specific mixtures of AHLs that can be recognized by members of its own species but also other bacterial species. Plant hosts can also detect these quorum-sensing signals in a structure and concentration-dependent way (Mathesius et al. 2003). Detection of AHLs by legumes changes the outcome of subsequent symbiosis with rhizobia, with exposure of plants to a symbiont-specific AHL leading to increased nodule numbers in Medicago truncatula (Palmer et al. 2016; Veliz-Vallejos et al. 2014, 2020). AHLs also affect plant defense responses and can induce systemic resistance to a number of fungal pathogens (Schenk et al. 2014; Schikora et al. 2011), although the subsequent response to plant parasitic nematode infection has not been tested, to our knowledge. AHLs can also be recognized by humans and animals, including nematodes (Teplitski et al. 2011). The bacterial-feeding nematode Caenorhabditis elegans

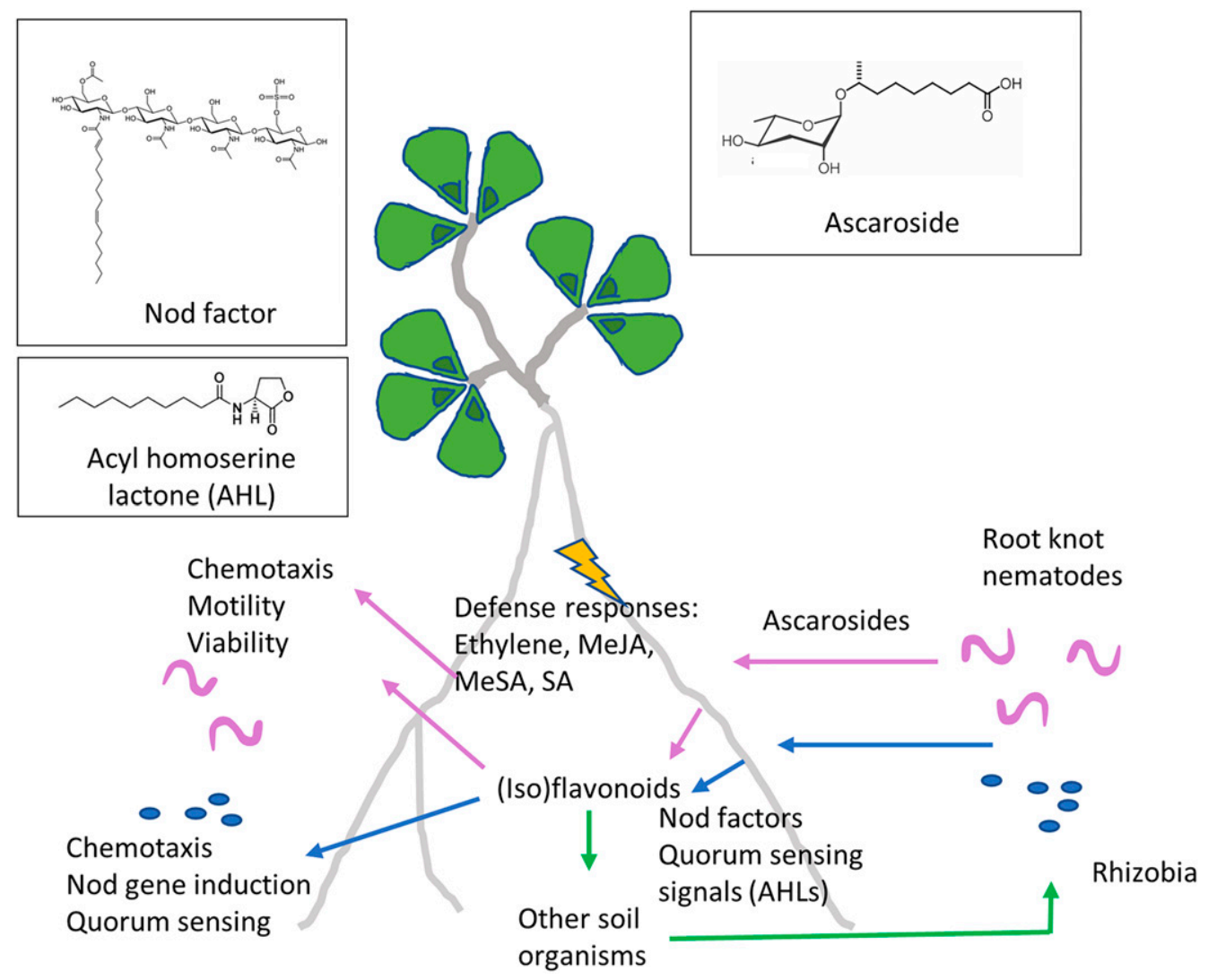

Fig. 3. Examples of rhizosphere chemical signaling that could influence the interaction of roots with both rhizobia and nematodes. Root-knot nematodes $(\mathrm{RKN})$ produce ascarosides in the rhizosphere. Rhizobia produce Nod factors, quorum-sensing signals, and other signals perceived by the host. Both rhizobia and nematodes can induce the production and exudation of (iso)flavonoids that can have functions in chemotaxis of rhizobia toward the root or attraction or repulsion of nematodes to and from the root. They can also inhibit nematode motility, further enhance or repress Nod gene expression in rhizobia, and alter production of rhizobial quorum-sensing signaling. Ascarosides as well as Nod factors, quorum-sensing signals, and surface polysaccharides of rhizobia can also modulate defense responses, which may have indirect effects on the tolerance of further infection with rhizobia or RKN. These can include induction of ethylene, methyl jasmonate (MeJA), methyl salicylate (MeSA), and salicylic acid (SA). Isoflavonoids can also influence other organisms in the rhizosphere that could indirectly interact with RKN or rhizobia or the host. For example, isoflavonoids can be inhibitors of fungal pathogens that may form secondary infections in roots infected by RKN. Note some of the structural similarities of the signaling molecules in the presence of a variable fatty acid side chain between Nod factors, ascarosides, and acyl homoserine lactones. 
can detect AHLs (Beale et al. 2006), and this likely provides an advantage in discriminating between bacterial species that this free-living nematode eats. Whether AHLs can be detected by plant parasitic nematodes and whether this is relevant for their interaction with their host or with bacteria in the rhizosphere would be interesting to test.

As mentioned above and shown in Figure 2, while AHLs, Nod factors, and ascarosides have distinct functions, they share a molecular structure characterized by variable length fatty acids that can mediate specificity. However, these signals are perceived by different types of receptors. Nod factors are perceived by legume LysM-type receptors (Bozsoki et al. 2020) similar to those binding chitin fragments. No definitive AHL or ascaroside receptors have been identified in plants, but animal cells use various $\mathrm{G}$ protein-coupled receptors to detect ascarosides (Kim et al. 2009). So far, there is evidence for AHL perception in animals through peroxisome proliferatoractivated receptors (Jahoor et al. 2008) and through the IQ motif-containing GTPase-activating protein IQGAP1 (Karlsson et al. 2012) but, also, for direct interaction of AHLs with certain membranes (Davis et al. 2010). It would be interesting to find out how the specificity of the fatty acid is mediated by ligand-receptor binding in these different receptors and why the fatty acid side chain plays a similar role in specificity in all three cases.

Apart from these quorum sensing-related signals, interaction of nematodes and rhizobia in the rhizosphere could also involve signals contained in root exudates (Fig. 3). Simple sugars, organic acids, and amino acids are attractants for both rhizobia and RKN (Tsai et al. 2020). Other root-exuded signals that affect both nematodes and rhizobia include flavonoids, a group of phenolic metabolites that play roles in many aspects of plantmicrobe interactions (Hassan and Mathesius 2012). Certain flavonoids can act as attractants or repellents for nematodes, including RKN in a concentration-dependent manner (Chin et al. 2018). These, as well as other molecules exuded from root tips play a role in movement of RKN toward host roots (Wuyts et al. 2006a; Wuyts et al. 2006b).

Likewise, flavonoids have several roles in the rhizobiumlegume symbiosis, first as chemo-attractants for rhizobia (Aguilar et al. 1988; Dharmatilake and Bauer 1992) and, then, as inducers (or repressors) of rhizobial nodulation genes (Peters et al. 1986; Redmond et al. 1986). This is necessary to induce production of Nod factors by rhizobia, which are the essential signals that induce nodule development and control infection of rhizobia. Rhizobia, as well as other rhizosphere bacteria, can also metabolize flavonoids and this could lead to structural conversions as well as breakdown of flavonoids in the soil, possibly altering their activity as nod gene inducers, chemoattractants, or phytoalexins (Rao and Cooper 1994).

Rhizobia induce not only the production of Nod geneinducing flavonoids but also flavonoids that are inhibitory for rhizobia or other organisms, e.g., the phytoalexins medicarpin and glyceollin (Mapope and Dakora 2013). Some inhibitory flavonoids could play a role in controlling rhizobial selection, for example, medicarpin can inhibit the growth of incompatible but not compatible rhizobia, which have gained the ability to metabolize it (Parniske et al. 1991). This may enable host plants to exude phytoalexins against other pathogens, including RKN, while still allowing symbiotic rhizobia to infect at the same time. For example, the induction of medicarpin and glyceollin by host plants has been linked to successful defense against RKN (Chin et al. 2018).

An additional function of certain flavonoids is the regulation of quorum sensing-related genes in rhizobia (Pérez-Montaño et al. 2011), although the detailed consequences of this for the symbiosis have not been explored. While legumes lacking flavonoids are unable to form infected nodules in legumes (Wasson et al. 2006), flavonoids are not necessary for the formation of galls by RKN (Wuyts et al. 2006a), although the galls that are formed are significantly smaller (Wasson et al. 2009). These experiments have, to our knowledge, not included tests with plants lacking flavonoids growing in nonsterile soil environments to test indirect effects of changes in flavonoid exudates on the whole root microbiome.

A further complicating factor in unraveling the interactions of rhizobia and RKN by rhizosphere signaling is that there are, of course, thousands of other species of organisms present that could contribute to or modify signals and responses. For example, nodulated plants have a different microbiome compared with uninfected plants (Zgadzaj et al. 2016). Plant exposure to AHLs also alters the root microbiome (Veliz-Vallejos et al. 2020). Some of these other bacterial inhabitants have also been found to have effects on soil nematodes or plant responses to soil nematodes (Topalović et al. 2020; Wei et al. 2014). This complexity is likely a contributing factor for the variation of outcomes observed in root-rhizobia-RKN interactions.

\section{OVERCOMING OF PLANT DEFENSE RESPONSES BY RHIZOBIA AND RKN DURING INFECTION}

Both RKN and rhizobia successfully invade the inside of plant roots without eliciting strong plant defense responses that could lead to cell death. Plant defense responses are typically induced by either pathogen-associated molecular patterns (PAMPs) or damage-associated molecular patterns (DAMPs) or by specific recognition of microbial effector proteins by the host. There is strong evidence that both rhizobia and RKN actively suppress plant defense responses and, also, that both have strategies to protect themselves from defense responses that are elicited. However, this is achieved in different ways.

Rhizobia invade roots either through crack-entry between cells or via infection threads, depending on the host (MassonBoivin et al. 2009) (Fig. 2A). During this infection step, they remain outside the plant cell wall. For infection thread formation, rhizobia initially need to dissolve the root-hair cell wall locally and, from that site, a new tubular cell wall grows toward the inside of the root hair, carrying rhizobia into deeper cell layers (Gage 2004). After traveling through the infection thread, rhizobia are released to the inside of plant cells in a process resembling endocytosis, but bacteria stay surrounded by the plasma membrane.

RKN initially invade roots intercellularly, moving between cells until they reach a site within the vascular cylinder (Fig. 2D). The migration through the root is thought to initiate minimal damage to cell walls, as plants with altered damage perception or altered production of polygalacturonase-inhibiting proteins show normal infection phenotypes (Teixeira et al. 2016). After selection of a site for feeding structure initiation, RKN then penetrate individual cells with their stylet and the help of cell wall-degrading enzymes and inject a large number of effectors that control defense responses, cell-wall modification, and giant cell formation (Mejias et al. 2019).

During both RKN and rhizobia infection events, evidence for repression of plant defense responses has been found. In both interactions, the types of plant defenses that are overcome are the physical barrier of the cell wall as well as chemical defenses, e.g., those mediated by phytoalexins and reactive oxygen species (ROS) (Gourion et al. 2015; Goverse and Smant 2014; Przybylska and Obrępalska-Stęplowska 2020; Zipfel and Oldroyd 2017).

Physical defense barriers are overcome by the movement of $\mathrm{RKN}$, the dissolution of cell walls due to penetration by the 
stylet, as well as injection of cell wall-degrading enzymes including cellulases, pectinases, and polygalacturonases (Mejias et al. 2019). Rhizobia also produce cell wall-degrading enzymes, e.g., cellulase, to initiate the infection thread (van Spronsen et al. 1994). Interestingly, even though generation of cell-wall fragments would induce typical plant defense responses (so-called DAMP responses), RKN and rhizobia evolved strategies to suppress those immune responses in compatible interactions. For example, salicylic acid (SA), a phytohormone commonly elevated during biotic stress, was downregulated during a compatible host-symbiont interaction compared with a noncompatible interaction (Martínez-Abarca et al. 1998). During infection thread initiation, production of cellulase by rhizobia at the root-hair tip is adjusted to its host and finely balanced to avoid excessive ROS responses in root hairs (Menéndez et al. 2019). The ROS response, as demonstrated by hydrogen peroxide efflux, was also downregulated when the legume root hairs were treated with purified Nod factors as opposed to a pathogenic response elicitor (Shaw and Long 2003). A comparison of defense responses triggered by rhizobia compared with less-compatible symbionts or pathogens showed that compatible rhizobia do not induce any of the typical defense responses, likely through repression of such responses by Nod factor signaling (Kelly et al. 2018). However, some very early and transient defense responses have also been inferred from transcriptome studies, although they are overshadowed by downregulation of later defense responses (El Yahyaoui et al. 2004; Kouchi et al. 2004; Moreau et al. 2011). A massive downregulation of defense responses was specifically observed in nodule zone II, in which rhizobia start to infect, similar to expression changes seen in giant cells (Damiani et al. 2012).

A further adaptation of rhizobia is to alter typical MAMPs on rhizobia surfaces. Common PAMPs, such as flagellin, on pathogenic bacterial and fungal surfaces can elicit a strong innate immune response in plant hosts, leading to hypersensitive or cell-death responses. However, flagellin epitopes from rhizobia have been significantly altered to the point that they do not induce a sustained pathogenic response in legume hosts (Lopez-Gomez et al. 2012). Exopolysaccharide structures on the surface of rhizobia are, furthermore, important for the control of plant defense responses, as demonstrated in exopolysaccharide mutants that show defects in nodule infection and differentiation (Arnold et al. 2018; Jones et al. 2008).

The first detection of nematodes inside the plant is likely the nematode cuticle, which consists of basal layers of collagen, covered in glycosylated proteins and peptides as well as lipids. Some RKN can change the surface coat in response to plant exudates and signals, and this might alter the ability of the plant to detect RKN (Davies and Curtis 2011). Whether the plant detects components of the nematode cuticle to activate defenses is not known. The main strategy that RKN deploy to subvert plant immune responses is to produce and inject effector proteins that actively suppress plant immune responses that are activated against PAMPs or DAMPs. The only known PAMP identified from parasitic nematodes, so far, is an ascaroside (ascr\#18), as mentioned above, although its receptor is unknown. Typical DAMPs are cell-wall fragments generated during tissue penetration of RKN. The subsequently activated immune responses include wall reinforcement, production of secondary metabolites that repel or kill nematodes, production of ROS and phytoalexins, as well as enzymes that target RKN.

However, compatible RKN actively attenuate these plant defense responses by secreting effectors through their stylet (Sato et al. 2019). Transcriptome studies have shown substantial downregulation of a suite of defense responses in the plant, likely mediated through nematode effectors (Barcala et al. 2010; Damiani et al. 2012; Jammes et al. 2005). For example, the RKN $M$. incognita secretes the MiMsp40 effector to prevent the deposition of callose and elicitor-triggered immunity (Niu et al. 2016). Chorismate mutase, an enzyme produced by RKN, can alter production of SA, which acts in systemic defense signaling as well as reducing precursors for the production of flavonoid phytoalexins (Doyle and Lambert 2003). Moreover, the macrophage migration inhibitory factors secreted by $M$. incognita can decrease flg22-triggered immune responses and weaken ROS responses (Zhao et al. 2019). RKN are also partially protected from a host immune response by producing enzymes that detoxify ROS (Henkle-Dührsen and Kampkötter 2001). All this allows RKN to survive immune responses by the host and continue their infection process to varying degrees. Resistance to RKN leading to cell death is activated only when certain resistance genes are present in the host, and these are typically of the nucleotide-binding siteleucine-rich repeat receptor type (Sato et al. 2019). RKNresistance genes $R k$ (Fery and Dukes 1980) and $R k^{2}$ (Roberts et al. 1996), which confer resistance to the most widespread species of RKN, have been described in cowpea (Vigna unguiculata) and have been conventionally bred into modern cowpea cultivars for RKN control. Interestingly, resistant cowpea plants with the $R k$ gene do not suppress root infection by the nematode, and a hypersensitive response with feeding site necrosis or significant ROS release is not triggered in this incompatible interaction. Rather, infective juveniles are able to enter the root, establish feeding sites and develop into females, until development is arrested before egg-laying, with giant cells deteriorating 2 to 3 weeks after inoculation (Das et al. 2008). To our knowledge, there has been no investigation of the possible effects of RKN resistance genes in legumes on nodulation, and this would be worth investigating in light of the overlapping changes in defense responses in response to RKN and rhizobia.

While the injection of effector proteins by $\mathrm{RKN}$ is ostensibly different from Nod factor signaling by rhizobia, a further similarity can be drawn by the transfer of rhizobial proteins into host cells by type III secretion systems (T3SS), which are typically utilized by plant pathogens (Deakin and Broughton 2009), somewhat reminiscent of infection of effector proteins by RKN through a stylet. While nodule outer proteins that are transferred via T3SS can improve nodulation with a specific host, they can reduce effectiveness of nonspecific rhizobia on other hosts (Staehelin and Krishnan 2015).

Plant defense-related hormones also play roles in both interactions. First, ethylene, typically induced during many defense responses, plays a negative role in nodulation, demonstrated in ethylene-insensitive mutants, which are hyperinfected by rhizobia (Miyata et al. 2013; Penmetsa and Cook 1997). Ethylene is a strong repellent against nematodes, and the $s k l$ mutant was shown to attract many more nematodes than wild-type roots (Čepulyte et al. 2018), even though it showed reduced gall numbers (Costa et al. 2020). This is surprising, as other pathogens also hyperinfect the $s k l$ mutant (Penmetsa et al. 2008), suggesting that ethylene plays a distinct role in nematode defense that will need to be explored in the future. In addition to ethylene, SA and JA are involved in systemic defense responses. Most studies on legumerhizobia symbioses found an inhibitory role for SA and JA in nodulation (Ferguson and Mathesius 2014). All three hormones are also more strongly induced in incompatible than in compatible plant-RKN interactions, suggesting a negative role in RKN infection (Bhattarai et al. 2008). SA and JA signaling is activated through perception of ascr\#18 (Sato et al. 2019), and both hormones can alter nematode motility (Sikder and Vestergård 2020) (Fig. 3).

A legume-specific arsenal of defense peptides is expressed in nodules and leads to terminal differentiation of bacteroids, so-called nodule-specific cysteine-rich peptides (NCP) (Van de 
Velde et al. 2010). Compatible rhizobia are resistant to these peptides, while noncompatible bacteria and a wide range of bacterial and fungal pathogens are repressed (Maróti et al. 2015). The action of NCP peptides on RKN has not been studied to our knowledge, but the observed preference for RKN to infect nodules might suggest that RKN are not affected by NCR peptides or infect cells in which NCP peptides are absent.

It is worth mentioning in this context that rhizobia are also able to protect nonlegumes from infection by RKN, although this might be through a different mechanism. For example, Rhizobium etli acts as a bacterial antagonist of RKN in tomato and this is largely mediated by induction of systemic resistance. Part of the bacterial lipopolysaccharides (LPS) are thought to be responsible for the systemic effect, in which rhizobia inoculated on one half of a split root system could protect a separate part of the root from RKN infection (Adam et al. 2014). Thus, while some aspects of the protective effect of rhizobia on RKN parasitism may be mediated by Nod factor signaling in legumes, an additional systemic effect can be triggered that is not nodulation-dependent. To our knowledge, it is unclear whether rhizobial LPS induce an induced systemic resistance effect in legumes that would deter RKN infection, but it is unlikely, since LPS of rhizobia generally reduce defense responses in legume hosts (Tellström et al. 2007).

Legume and rhizobial coevolution is likely to have favored adaptations that make symbioses more host-specific, which has led to specifications in Nod factor recognition, responses to specific exopolysaccharide, and resistance of rhizobia to plant immune peptides inside the nodule. In contrast, RKN evolution would have favored a continuous change and diversification of effector proteins and epitopes that subvert plant detection and immune responses. The large number and diversity of nematode effectors, their ability to 'hijack' a multitude of existing plant signaling pathways and to suppress plant immune responses is likely the reason for their wide host range and existence of limited plant resistance.

\section{OVERLAPPING DEVELOPMENTAL SIGNALS}

Even though nodules and galls differentiate into distinct organs, their organogenesis programs share some similarities. In both cases, the invading organism initiates new cell divisions and alters cell differentiation. Nodules are initiated with the reinitiation of cell divisions in the pericycle and cortex, with some involvement of endodermal cells in a patch of cells underneath the infection site (Xiao et al. 2014) (Fig. 2B). In developing nodules, cell divisions continue in the nodule meristem, but cell enlargement and endoreduplication occurs in cells in zone II of the nodule, where rhizobia start to infect nodule cells (Damiani et al. 2012; Roudier et al. 2003). Gall development is triggered by the initial formation of giant cells, while pericycle and cortical cell divisions are initiated in a circle around the expanding stele (de Almeida Engler and Gheysen 2013) (Fig. 2E). Giant cell formation involves multiple rounds of mitosis without cytokinesis, followed by endoreduplication, resulting in multinucleate cells (Goverse et al. 2000). The cell cycle regulator CCS52 (CELL CYCLE SWITCH 52) is required for the endoreduplication step in giant cells as well as in zone II of legume nodules (de Almeida Engler et al. 2012; Vinardell et al. 2003).

Two crucial plant hormones are essential for cell division and differentiation, auxin and cytokinin, and both have been implicated in nodulation and gall formation. There is evidence that rhizobia and RKN can synthesize auxins and cytokinins directly, but auxin and cytokinin synthesis and perception are also altered by Nod factor signaling and through nematode effectors. Likely in response to these hormones, a number of cell cycle proteins (cyclins and cyclin-dependent kinases) are then activated in the dividing cells, and some of these overlap in function in both organogenesis programs.

In contrast, cells in the pericycle and cortex divide by normal cytokinetic mitosis around the giant cells. In both cases, the cyclin genes $C y c 2 a, C y c 2 b$, and $C y c A 2 ; 1$ indicate activation of mitotic divisions (Goverse et al. 2000). CycA2;2 is activated by auxin in dividing cells of nodule (and root) primordia but not in endoreduplicating cells in RKN feeding sites (Roudier et al. 2003). This agrees with observations of auxin-responsive promoter/reporter fusions, which are typically induced in dividing cells around giant cells but not inside giant cells (Hutangura et al. 1999; Karczmarek et al. 2004; Olmo et al. 2020). They are also activated in dividing pericycle and cortical cells of young nodule primordia (Kohlen et al. 2018). PIN (PIN-FORMED) and AUX1/LAX (AUXIN/LIKE AUX1) auxin transport genes have also been localized in nodule primordia (de Billy et al. 2001; Huo et al. 2006) and expression of auxin transporter genes has been found to be elevated in giant cells (Hammes et al. 2005; Kyndt et al. 2016). The similarities in auxin responses in dividing cells of galls and nodules are not surprising in light of the fundamental role of auxin in plant organ initiation (Benkovà et al. 2003).

The essential role for auxin in feeding site formation was hypothesized because the auxin-insensitive diageotropica mutant of tomato fails to form a feeding site after infection of RKN (Richardson and Price 1984). Auxin could be directly contributed by RKN secretions (De Meutter et al. 2005) or it could be accumulated through auxin export inhibition in galls, possibly through accumulation of flavonoids that act as polar auxin transport inhibitors (Hutangura et al. 1999; Wasson et al. 2009), similar to the inhibition of auxin transport by flavonoids during the development of indeterminate nodules, which is controlled by Nod factor perception (Wasson et al. 2006; Zhang et al. 2009). While lack of flavonoids completely inhibits nodulation, it does not prevent giant-cell formation or nematode reproduction (Wasson et al. 2009; Wuyts et al. 2006a), although pericycle cell divisions are reduced in the resulting galls in Medicago truncatula, suggesting a role for flavonoids in pericycle cell division. However, whether the absence of flavonoids prevents auxin transport control by RKN has not been directly tested. Further support for the redirection of auxin transport in gall development comes from expression studies of $A U X 1 / L A X$ and $P I N$ auxin transporter genes during gall formation and from observations of reduced gall formation in the Arabidopsis auxl, lax3, pin2, and pin3 auxin import and export mutants (Kyndt et al. 2016). Only MtLAX2 has been implicated, so far, in nodule development (Roy et al. 2017). The RKN effector chorismate mutase could also affect auxin and flavonoid accumulation, as it catalyzes the production of both auxin and flavonoid precursors (Doyle and Lambert 2003), although its direct involvement has not yet been tested in mutants. Interestingly, changes in auxin accumulation could directly affect $\mathrm{RKN}$, as auxins can induce stylet thrusting as well as enhancing the movement of RKN, which may attract $\mathrm{J} 2$ to the infected root or to sites of auxin accumulation in the root (Curtis 2007, 2008), possibly also to nodules.

In addition to auxin, the phytohormone cytokinin plays a crucial role in both interactions. As for auxin, there is evidence for the production of cytokinins by RKN (De Meutter et al. 2003), although its importance is difficult to test because it is currently not possible to genetically transform RKN. Strong cytokinin responses occur in nodule primordia in various legumes (Lohar et al. 2004; Plet et al. 2011). Cytokinin signaling is essential for nodule initiation, as cytokinin-insensitive mutants form significantly fewer nodules (Murray et al. 2007; Plet et al. 2011), whereas constitutive expression of a cytokinin 
receptor or application of cytokinin directly causes spontaneous nodule formation (Gauthier-Coles et al. 2018; Tirichine et al. 2007). While the Medicago truncatula crel mutant is defective in nodulation, it still forms galls and giant cells (Costa et al. 2020). However, this may be a result of the redundancy of cytokinin receptors, because the Arabidopsis histidine kinase receptor mutants $a h k 2 / 3$, ahk2/4, and $a h k 3 / 4$ had significantly reduced gall numbers (Dowd et al. 2017). In addition, reducing cytokinin concentrations by overexpression of cytokinin oxidase reduced both nodule and gall numbers in Lotus japonicus (Lohar et al. 2004) and Arabidopsis (Dowd et al. 2017). Cytokinin responses were found in the dividing parenchyma, pericycle, and cortical cells surrounding the expanding giant cells but not the giant cells themselves after the very early stages, similar to the localization of auxin responses (Lohar et al. 2004). A direct semiquantitative comparison of auxin and cytokinin responses in early galls showed a stronger auxin response than cytokinin response in Arabidopsis (Olmo et al. 2020).

While the relative contributions of cytokinins and auxins to nodule and gall development remain unclear, their subsequent action on a number of transcription factors that control cell division and differentiation has uncovered several crucial differences between nodule and gall specification. One of the most interesting players in both nodule and gall development is the transcription factor LBD16 (LATERAL ORGAN BOUNDARIES-DOMAIN 16), which is also involved in lateral root formation. $L B D 16$ expression is activated in dividing cells of galls and nodules, and its downregulation leads to reduced nodule and gall numbers as well as giant cell size (Cabrera et al. 2015; Schiessl et al. 2019; Soyano et al. 2019). LBD16 expression can be activated by auxin signaling and this has been suggested to occur in developing galls, similar to its regulation during lateral root formation (Cabrera et al. 2015). During nodulation, $L D B 16$ is activated in the cortex via cytokinin signaling through a crucial nodulation transcription factor called NIN (NODULE INCEPTION) and is required for subsequent recruitment of the nodulation transcription factor NF-Y (Soyano et al. 2019) and for auxin synthesis (Schiessl et al. 2019). Interestingly, the gene encoding LBD16 has been duplicated in legumes, and it has been suggested that one copy has gained a specific function for activating nodulation in legumes by acquiring a specific promoter activation site for NIN (Liu et al. 2019) Together with finding that a nodulationspecific legume NIN requires a particular promoter element for its activation in the pericycle and later the inner cortex and that NIN is activated by cytokinin (Liu et al. 2019), these studies suggest that legumes have gained a specific regulatory circuit connecting cytokinin responses with activation of NIN and, subsequently, LBD16 in pericycle and cortical cells to initiate nodules. This appears to be in contrast to the hypothesized activation of LBD16 by auxin in the pericycle during lateral root and gall development (Cabrera et al. 2015), although infection phenotypes of RKN in legume lbd16 mutants should be tested. Supporting a specific role for cytokinin-NIN-LBD16 signaling in nodulation is the finding that, in Medicago truncatula, NIN is not required for gall formation, nor are the upstream nodulation signaling genes NFP1 (encoding a Nod factor receptor), NSP2 (encoding a transcription factor), or CRE1 (encoding a nodulation-specific cytokinin receptor) (Costa et al. 2020). However, in L. japonicus, reduced galls were found in the Nod factor perception mutants $n f r l$ and $n f r 5$ (Weerasinghe et al. 2005). The ability of nodulating legumes but not nonnodulating legumes or nonlegumes to respond to cytokinin with pseudo-nodule development in the cortex further strengthens the specific role of cytokinin in the root cortex during legume nodulation (Gauthier-Coles et al. 2018).

Another modified regulatory circuit that has been gained in legumes to enable nodulation has emerged as the SHR-SCR (SHORTROOT-SCARECROW) interaction, which has been shown to have an essential and specific role in the legume root cortex to enable cortical nodule development (Dong et al. 2020). The activation of cortical cell division by cytokinin application or by ectopic NIN expression required $S H R$ and $S C R$, thus placing the cortex-specific activation of $S H R$ and $S C R$ in legumes downstream of cytokinin-NIN signaling, similar to LBD16 (Dong et al. 2020).

$S C R$ and $S H R$ expression are also activated during gall formation and scr and shr mutants are characterized by reduced numbers of galls in Arabidopsis, supporting the hypothesis that both nodule and gall development have recruited common genes necessary for controlling meristematic activity in the root (Olmo et al. 2020). As gall development does not appear to require NIN, it may be the activation of SHR and SCR by different signals and in different cell types that would set apart the role of these transcription factors in nodule and gall initiation.

In addition to auxin and cytokinin-regulated responses, abscisic acid (ABA) plays an important role in root organ development, as demonstrated in the ABA-insensitive LATD/NIP mutant of Medicago truncatula, which forms defective root apical, lateral root, and nodule primordia, while only small, white nodules are formed on the roots (Bright et al. 2005). The mutant also showed somewhat reduced numbers of galls (Costa et al. 2020). Interestingly, legumes show a different (lateral root) response to ABA compared with nonlegumes, suggesting that apart from cytokinin responses, ABA responses could also play a specific role in legumes (Liang and Harris 2005).

The extensive overlap of genes similarly expressed in nematode- and rhizobia-infected roots and the functional requirement for some of these genes in both organogenesis programs (Table 3) provide strong evidence for the idea that genes involved in aspects of root development have been repurposed by RKN and rhizobia during evolution. The crucial specificity of these genes in both developmental programs has likely been gained through gene duplication and promoter alterations that enabled their specific activation in precursors cells for nodules and galls (Liu and Bisseling 2020).

\section{COMPETITION FOR NUTRIENTS FROM THE HOST}

Both nodules and giant cells inside galls become nutrient sinks in the root. Both organs are well-vascularized; vascular tissue typically forms on the periphery of the nodule, while giant cells inside galls are surrounded by a wound-type xylem and phloem that is extensively branched (Fig. 2). Giant cells and cells within the nodule vascular tissue, located between the endodermis and phloem and xylem cells, show characteristics of transfer cells with typical cell-wall ingrowths to maximize the surface area for nutrient transfer to and from the phloem and xylem (Pate and Gunning 1972; Rodiuc et al. 2014). While giant cells are directly connected to phloem and xylem, rhizobia are contained inside vesicles (symbiosomes) in infected nodule cells. Thus, transport into bacteroids requires transfer of nutrients from the nodule vascular tissue into the nodule and then from within infected host cells across the symbiosome (plant) and bacteroid (bacterial) membranes (Udvardi and Poole 2013), affording more control by the host.

Nodules require large amounts of carbohydrates, mainly in the form of sucrose from photosynthesis, which is transported 
to nodules via the phloem, likely exported by sucrose transporters of the SWEET family (Kryvoruchko et al. 2016; Sugiyama et al. 2017), metabolized by sucrose synthase, and converted to organic acids like malate, which are then transported into symbiosomes and metabolized inside bacteroids to fuel nitrogen fixation (Udvardi and Poole 2013). This cost has been estimated at around $6 \mathrm{~g}$ of carbon necessary for the fixation of $1 \mathrm{~g}$ of nitrogen, although the gain in fixed nitrogen compensates for this cost (Vance and Reichel 1991). There is no broad evidence that the cost of nitrogen fixation limits yields in most legumes, although environmental stress can alter that to some extent. The transfer of nutrients between host and symbiont, first from the nodule vascular tissue into the nodule and then across the symbiosome membrane, is controlled by a large number of transport proteins, some identified and some hypothesized (Clarke et al. 2014). The importance of sucrose for nitrogen fixation is highlighted by observations of reduced nodulation and nitrogen fixation in legumes with reduced

Table 3. Genes affecting rhizobia and root-knot nematode (RKN) interactions

\begin{tabular}{|c|c|c|c|}
\hline \multirow[b]{2}{*}{ Gene and plant species tested } & \multicolumn{2}{|c|}{ Phenotypes of mutant } & \multirow[b]{2}{*}{ References } \\
\hline & Nodulation & RKN & \\
\hline $\begin{array}{l}\text { NFP1 (NOD FACTOR PERCEPTION } \\
\text { 1) Medicago truncatula }\end{array}$ & No nodules or infections & Normal galls and reproduction & $\begin{array}{l}\text { Amor et al. 2003; Arrighi et al. 2006; } \\
\text { Costa et al. } 2020\end{array}$ \\
\hline $\begin{array}{l}\text { NFRII/5 (NOD FACTOR RECEPTOR } \\
\text { 1/5) Lotus japonicus }\end{array}$ & No nodules or infections & Fewer galls & $\begin{array}{l}\text { Radutoiu et al. 2003; Weerasinghe } \\
\text { et al. } 2005\end{array}$ \\
\hline $\begin{array}{l}\text { NSP2 (NODULATION SIGNALING } \\
\text { PATHWAY 2) Medicago truncatula }\end{array}$ & No nodules or infections & Normal galls and reproduction & Costa et al. 2020; Kaló et al. 2005 \\
\hline $\begin{array}{l}\text { NIN (NODULE INCEPTION) } \\
\text { Medicago truncatula }\end{array}$ & No nodules or infection & Normal galls and reproduction & $\begin{array}{l}\text { Costa et al. 2020; Marsh et al. 2007; } \\
\text { Schauser et al. } 1999\end{array}$ \\
\hline $\begin{array}{l}\text { CRE1 (CYTOKININ RECEPTOR 1) } \\
\text { Medicago truncatula; HIT1 } \\
\text { (HYPERINFECTED 1) L. } \\
\text { japonicus; AHK2/3/4 } \\
\text { (ARABIDOPSIS HISTIDINE } \\
\text { KINASE2/3/4) Arabidopsis }\end{array}$ & $\begin{array}{l}\text { No or few and delayed nodules, } \\
\text { infections present }\end{array}$ & $\begin{array}{l}\text { Normal galls and reproduction in } \\
\text { Mtcre1; reduced galls in Atahk } 2 / 3 \text {, } \\
\text { Atahk } 2 / 4, \text { Atahk } 3 / 4\end{array}$ & $\begin{array}{l}\text { Costa et al. 2020; Dowd et al. 2017; } \\
\text { Murray et al. 2007; Plet et al. } 2011\end{array}$ \\
\hline $\begin{array}{l}\text { CKX (CYTOKININ OXIDASE) } \\
\text { destroys active cytokinins; } L \text {. } \\
\text { japonicus }\end{array}$ & $\begin{array}{l}\text { Reduced nodules in } C K X \\
\text { overexpression transgenic roots }\end{array}$ & $\begin{array}{l}\text { Reduced galls in } C K X \text { overexpression } \\
\text { transgenic roots }\end{array}$ & Lohar et al. 2004 \\
\hline $\begin{array}{l}\text { PIN2 (PINFORMED2 auxin exporter) } \\
\text { Medicago truncatula and } \\
\text { Arabidopsis }\end{array}$ & No change in nodulation in Mtpin 2 & Reduced gall numbers in Atpin 2 & Kyndt et al. 2016; Ng et al. 2020 \\
\hline $\begin{array}{l}\text { AUX1/LAX (AUXIN1/LIKE AUX1 } \\
\text { auxin importers) Medicago } \\
\text { truncatula and Arabidopsis }\end{array}$ & Reduced nodule numbers in Mtlax 2 & Reduced numbers of galls in Atauxl & Kyndt et al. 2016; Roy et al. 2017 \\
\hline $\begin{array}{l}\text { CCS52 (CELL CYCLE SWITCH 52) } \\
\text { required for endoreduplication; } \\
\text { Medicago truncatula and } \\
\text { Arabidopsis }\end{array}$ & $\begin{array}{l}\text { Reduced ploidy levels in nodules; } \\
\text { small, early senescing non-nitrogen } \\
\text { fixing nodules; no effect on nodule } \\
\text { primordium formation in antisense } \\
\text { ccs52A Medicago truncatula } \\
\text { transgenics }\end{array}$ & $\begin{array}{l}\text { Defects in giant cell and gall } \\
\text { expansion and maturation in CCS52 } \\
\text { knockdown lines in Arabidopsis }\end{array}$ & $\begin{array}{l}\text { de Almeida Engler et al. 2012; } \\
\text { Vinardell et al. } 2003\end{array}$ \\
\hline $\begin{array}{l}\text { SKL (SICKLE; ethylene insensitive) } \\
\text { encodes EIN2, Medicago } \\
\text { truncatula, ETR1 (ETHYLENE } \\
\text { RESPONSE1) L. japonicus }\end{array}$ & Hypernodulation and hyperinfection & $\begin{array}{l}\text { Fewer galls and eggs; stronger } \\
\text { attraction of nematodes to roots in } \\
\text { skl; no change in gall numbers in } \\
\text { etrl }\end{array}$ & $\begin{array}{l}\text { Čepulyte et al. 2018; Costa et al. } \\
\text { 2020; Lohar and Bird 2003; } \\
\text { Penmetsa and Cook } 1997\end{array}$ \\
\hline $\begin{array}{l}\text { LATD /NIP (LATERAL ROOT- } \\
\text { ORGAN DEFECTIVE/NUMEROUS } \\
\text { INFECTIONS AND } \\
\text { POLYPHENOLICS) ABA } \\
\text { insensitive, Medicago truncatula }\end{array}$ & $\begin{array}{l}\text { Fewer nodules, small and white } \\
\text { nodules }\end{array}$ & $\begin{array}{l}\text { Somewhat fewer galls with normal } \\
\text { reproduction }\end{array}$ & Bright et al. 2005; Costa et al. 2020 \\
\hline $\begin{array}{l}\text { LBD16 (LATERAL ORGAN } \\
\text { BOUNDARIES DOMAIN 16) } \\
\text { Medicago truncatula and L. } \\
\text { japonicus, Arabidopsis }\end{array}$ & Reduced numbers of nodules & Reduced numbers of galls & $\begin{array}{l}\text { Cabrera et al. 2015; Schiessl et al. } \\
\text { 2019; Soyano et al. } 2019\end{array}$ \\
\hline $\begin{array}{l}\text { SHR and SCR (SHORTROOT, } \\
\text { SCARECROW) Medicago } \\
\text { truncatula and Arabidopsis }\end{array}$ & Reduced numbers of nodules & Reduced numbers of galls & Dong et al. 2020; Olmo et al. 2020 \\
\hline $\begin{array}{l}\text { CHS (CHALCONE SYNTHASE) } \\
\text { production; of all flavonoid } \\
\text { precursors, Medicago truncatula } \\
\text { and Arabidopsis }\end{array}$ & No nodules in $C H S$-silenced roots & $\begin{array}{l}\text { Smaller galls with fewer pericycle } \\
\text { divisions in CHS-silenced Medicago } \\
\text { truncatula roots; normal galls and } \\
\text { reproduction in Arabidopsis tt4 (chs } \\
\text { mutant }\end{array}$ & Wasson et al. 2009; Wuyts et al. 2006a \\
\hline $\begin{array}{l}\text { SUNN4 (SUPER NUMERIC } \\
\text { NODULES4) Medicago truncatula; } \\
\text { HAR1 (HYPERNODULATION } \\
\text { ABERRANT ROOT1) L. japonicus }\end{array}$ & Supernodulation & $\begin{array}{l}\text { Normal galls and eggs in sunn } 4 \text {; } \\
\text { twofold increased number of galls in } \\
\text { harl without expanded zone of galls } \\
\text { on root and without reduced plant } \\
\text { growth }\end{array}$ & $\begin{array}{l}\text { Costa et al. 2020; Lohar and Bird } \\
\text { 2003; Nishimura et al. 2002; } \\
\text { Schnabel et al. } 2005\end{array}$ \\
\hline SUS (SUCROSE SYNTHASE) & $\begin{array}{l}\text { Reduced nodule numbers and } \\
\text { nitrogen fixation (antisense } \\
M t S u c S 1 \text { expression) }\end{array}$ & $\begin{array}{l}\text { Increased gall numbers in Arabidopsis } \\
\text { sus } 1 / \text { sus } 4 \text { mutant }\end{array}$ & Baier et al. 2007; Cabello et al. 2014 \\
\hline
\end{tabular}


sucrose synthase expression (Baier et al. 2007; Gordon et al. 1999), although mutation of the sucrose transporter gene SWEET11 did not compromise nitrogen fixation, likely because of transporter redundancy (Kryvoruchko et al. 2016). Ammonium is exported from bacteroids and quickly assimilated into amino acids by the plant (Clarke et al. 2014; Udvardi and Poole 2013).

In contrast to nodules, nematodes feeding inside galls are purely parasitic and confer significant yield penalties to the host (Moens et al. 2009). While legumes are able to control carbohydrate allocation toward nodules and 'sanction' ineffective nodules in which poorly nitrogen-fixing rhizobia become parasitic (Kiers and Denison 2008; Oono et al. 2011), there is no evidence, to our knowledge, that host plants can limit the nutrient transfer to galls in compatible interactions (Bartlem et al. 2014). The mechanism of sanctioning nodules by reducing carbon allocation is not known. It could involve regulating the activity of some of the transport proteins controlling import of nutrients into symbiosomes. Giant cells are symplastically isolated from the phloem, although they can be connected by plasmodesmata to each other (Rodiuc et al. 2014), and carbohydrate transport into giant cells is regulated by several families of sugar transporter proteins (Bartlem et al. 2014). Many other genes encoding transport proteins have been identified as being differentially expressed in giant cells, for example, the sucrose transporter SUC1, $\mathrm{Ca}^{2+}$-ATPases, amino acid transporters, and aquaporins were upregulated in giant cells, while peptide transporters were downregulated (Hammes et al. 2005). Not surprisingly, some of these are similar to transporters upregulated in nodules, including $\mathrm{H}^{+}-$and $\mathrm{Ca}^{2+}$. ATPases and aquaporins, although the exact substrates for these remain to be determined (Clarke et al. 2014). In the future, it would be interesting to quantitatively assess the reallocation of (e.g., radiolabeled) carbon in a host infected by just a symbiont, compared with a combined infection by rhizobia and RKN, to model the relative competition between nodules and galls. An additional consideration regarding the effect of nutrient allocation is that rhizobia, while competing for carbon, benefit the plant and the carbon budget, by improving nitrogen nutrition, much of which is needed for RUBISCO synthesis and, thus, photosynthesis (Evans and Clarke 2019).

Because of the necessity to balance the need for nitrogen with the carbon cost of nodulation, legumes have evolved an autoregulatory system to limit nodule numbers (Ferguson et al. 2019). Rhizobia induce the production of specific CLE (CLAVATA3/ESR-RELATED) peptides in roots that travel to the shoot, where they bind a receptor-like kinase, resulting in the movement of an inhibitory signal to the root to limit further nodule development. Autoregulation mutants lacking the function of the receptor-like kinase in the shoot supernodulate and typically incur a biomass penalty (Nishimura et al. 2002. Schnabel et al. 2005; Searle et al. 2003). While the L. japonicus harl (hypernodulation aberrant root1) autoregulation mutant was reported to form increased numbers of galls (Lohar and Bird 2003), the Medicago truncatula sunn4 (super numeric nodules4) autoregulation mutant was not (Costa et al. 2020), leaving the question of whether galls are similarly autoregulated to nodules open to further scrutiny. It would be interesting to conduct these experiments under similar conditions with the same RKN species. Coinoculation experiments on the sunn 4 mutant with rhizobia and RKN showed no evidence that RKN interfered with the supernodulation phenotype (Costa et al. 2020).

\section{INDIRECT INTERACTIONS OF RHIZOBIA AND NEMATODES BY ALTERATION OF ROOT ARCHITECTURE}

So far, there are few studies that have systematically studied the effects of rhizobia and RKN on root architecture to test whether this affects infection of the other organism. Both organogenesis programs target some genes involved in lateral root development (Damiani et al. 2012; Olmo et al. 2020; Schiessl et al. 2019; Soyano et al. 2019). In theory, the emergence of new lateral roots as a result of nematode or rhizobia infection could create more entry points for infection of both

Table 4. Unanswered questions about root-rhizobia-RKN (root-knot nematode) interactions and suggestions for future experiments

\begin{tabular}{|c|c|}
\hline Unanswered questions & Suggested further testing of unknown effects \\
\hline \multicolumn{2}{|l|}{ How could improved nodulation affect RKN parasitism? } \\
\hline $\begin{array}{l}\text { Inoculation with highly competitive rhizobial strains could alter effect } \\
\text { that native rhizobia have on RKN infection }\end{array}$ & $\begin{array}{l}\text { Compare effects of competitive and highly } \mathrm{N}_{2} \text {-fixing strains with those of } \\
\text { native strains on their ability to reduce RKN infection }\end{array}$ \\
\hline $\begin{array}{l}\text { Increased rhizobia density in the soil could reduce viability of RKN eggs } \\
\text { in soil }\end{array}$ & Test if this is relevant at typical soil densities of rhizobia \\
\hline $\begin{array}{l}\text { Root interaction with rhizobia could alter the rhizosphere microbiome } \\
\text { in a way that suppresses or enhances RKN in soil }\end{array}$ & $\begin{array}{l}\text { Quantify changes in microbiome composition and test if particular } \\
\text { rhizosphere inhabitants have effects on RKN }\end{array}$ \\
\hline $\begin{array}{l}\text { Root exudates induced by rhizobia could enhance or reduce movement } \\
\text { of RKN to the root }\end{array}$ & $\begin{array}{l}\text { Test if mutants or transgenics with altered exudates have biological effects } \\
\text { on nematode chemotaxis, motility or survival }\end{array}$ \\
\hline $\begin{array}{l}\text { Reduced defense responses during nodulation could allow greater RKN } \\
\text { infection }\end{array}$ & $\begin{array}{l}\text { Test RKN infection of defense-related legume mutants in the presence or } \\
\text { absence of rhizobia, including rhizobia mutants that have known defects } \\
\text { in immune suppression or a range of native rhizobia varying in infectivity }\end{array}$ \\
\hline $\begin{array}{l}\text { Alteration in hormone transport or accumulation could indirectly affect } \\
\text { development of galls }\end{array}$ & Test concurrent development of nodules and galls in hormone mutants \\
\hline $\begin{array}{l}\text { Improved } \mathrm{N} \text { nutrition in nodulated plants could lead to higher tolerance } \\
\text { of RKN infection }\end{array}$ & Test rhizobia-RKN interaction with nitrogen fixation mutants \\
\hline Nodules could reduce galls by competing for photosynthates & $\begin{array}{l}\text { Quantitative tests for direct competition for } \mathrm{C} \text { by both organisms; test if } \\
\text { high } \mathrm{CO}_{2} \text { might alleviate effects }\end{array}$ \\
\hline $\begin{array}{l}\text { Rhizobia could increase root branching and create more entry points for } \\
\text { RKN, or at the same time create further carbon sinks in those lateral } \\
\text { roots }\end{array}$ & Test RKN infection in lateral root mutants of legumes \\
\hline \multicolumn{2}{|l|}{ How could enhanced resistance to RKN affect nodulation? } \\
\hline $\begin{array}{l}\text { Introduction of resistance }(R) \text { genes into legumes could trigger defense } \\
\text { responses to RKN that have indirect negative effects on nodulation }\end{array}$ & $\begin{array}{l}\text { Test if introduction } R \text { genes into legumes alters nodulation in the presence } \\
\text { and absence of RKN }\end{array}$ \\
\hline $\begin{array}{l}\text { Selecting or engineering of legumes with enhanced constitutive defenses } \\
\text { (structural or phytochemical) could reduce rhizobia infection }\end{array}$ & Test respective plant genotypes for nodulation \\
\hline $\begin{array}{l}\text { Reduced numbers of galls would reduce competition for photosynthates } \\
\text { (or other nutrients with nodules) }\end{array}$ & $\begin{array}{l}\text { Quantitative tests for direct competition for } \mathrm{C} \text { by both organisms; test if } \\
\text { high } \mathrm{CO}_{2} \text { might alleviate effects }\end{array}$ \\
\hline
\end{tabular}


organisms, as both infect the root system at or near the root tip (Bhuvaneswari et al. 1981; Gheysen and Mitchum 2011). On the other hand, formation of more lateral roots by the host could also redirect more resources toward lateral root development, and this could potentially reduce resources allocated toward other root organs. It has frequently been observed that RKN infection and gall formation stimulate the emergence of multiple lateral roots at or near a gall (Olmo et al. 2017) (Fig. 1C). Rhizobia also affect lateral root development directly and indirectly through altered root nutrient status (Concha and Doerner 2020). Application of Nod factors to roots of Medicago truncatula stimulated lateral root initiation under in-vitro conditions, likely mediated through auxin signaling (Herrbach et al. 2017). However, after several weeks of growth in pots, Medicago truncatula genotypes with more nodules had fewer lateral roots, pointing to a trade-off that could be due to nutrient competition between both organs (Goh et al. 2019). It would be worth testing the interaction between root architecture and nodulation and nematode parasitism more specifically by investigating gall and nodule formation in lateral root mutants of legumes.

\section{FINAL CONSIDERATIONS ON APPLICATIONS}

Legume crops and cover crops have been used in agriculture since ancient times to increase crop diversity and resource use, decrease soil erosion, and improve soil fertility and structure due to nitrogen fixation and rhizodeposition of organic matter. Nutrient leaching is prevented through the longer-term enrichment of nitrogen in the agroecosystem that sustainably reduces the gap between the attainable and the actual yield of the following cash crop. This multifunctionality granted by legume cover cropping or intercropping cannot simply be replaced by synthetic inputs and improves agroecosystem resilience (Gaudin et al. 2013). In addition, nitrogen fertilizers cause extensive problems with leaching of nitrate and $\mathrm{N}_{2} \mathrm{O}$ into the environment (Fustec et al. 2010). Nitrogen fixation by plant-rhizobial associations alone represent an estimated US\$10 billion annual saving in synthetic fertilizer use, which is particularly relevant for low-income farmers and low-input agroecosystems (Rodríguez-Navarro et al. 2011). Literature is scarce on the potential of legumes, either as main, cover, or intercrops to control RKN that can be inferred from the direct and indirect rhizobia-plant-nematode interactions described herein. Any potential legumes for agroecosystem use would need to be screened for host reaction to RKN, as many legumes usually used in crop rotations are susceptible to nematodes (McSorley 1999). Often, cover crops consist of mixtures of plants comprising not only legumes but also grasses or crucifers that assure pest and disease suppression; the main role of legumes in the mixtures is the nitrogen-fixation ability of rhizobia in root nodules, and this is the most economically relevant reason for including legumes in cover cropping (Couëdel et al. 2019).

The last few decades have seen a large research and industry investment in controlling nodulation in legumes to boost the agroecosystem service of nitrogen fixation for legume crop performance and for soil nutrient enrichment. For example, soybean is one of the most produced legumes in the world, and its seed is routinely inoculated with commercial, highly efficient Bradyrhizobium strains to ensure and harmonize nodulation and nitrogen fixation in the crop (Streeter 1994). In temperate climates, like in central Europe, there are no native rhizobia in soils that can nodulate soybean, so seed inoculation is crucial for crop performance, even if the lower temperatures do not always allow for the desired levels of nodulation and nitrogen fixation (Zimmer et al. 2016). On the other hand, in tropical climates, an abundant and diverse population of indigenous rhizobia that can form associations with soybean is available in the field. These indigenous rhizobia are welladapted to local conditions and tend to outcompete the commercial inoculant strains (Rodríguez-Navarro et al. 2011; Streeter 1994). Local rhizobial strains can be resilient to abiotic stress of various sources ( $\mathrm{pH}$, salinity, temperature) but may not be as effective nitrogen fixers as the exotic inoculants.

The role of this large taxonomic and functional diversity of rhizobia is unknown and underexplored but could account for the different outcomes of rhizobia-plant-nematode interactions presented (Table 2). This variability gives both fundamental and applied scientists a glimpse of the striking biodiversity associated with real agroecosystems and calls for research to establish its role. Given the variation in response to environmental conditions of different rhizobia, one might think there is functional redundancy in this group of bacteria; in an analogy of the spare wheel hypothesis (Andrén et al. 1995), depending on abiotic conditions, some rhizobia strains would prevalently form associations with plants, whether or not they are effective nitrogen fixers. The differing nodulation levels could relate to environmental conditions and plant regulation, but, as presented above, can also be affected by interactions with nematodes, with outcomes depending on several factors. Therefore, one cannot exclude the idea that, instead of being functionally redundant, rhizobia may also present variability in the rhizobiaplant-nematode interaction, inducing different outcomes. One may speculate that deterring plant infection by nematodes could be an unanticipated function of rhizobia and that a plant trade-off between recruiting rhizobia with poor nitrogenfixation ability that can, however, reduce infection by nematodes would maintain diversity in the nitrogen-fixation trait in rhizobia. To our knowledge, there are no published studies to support this, and future research should address this hypothesis.

Regarding crop improvement, the studies evaluated here offer two perspectives, engineering nitrogen-fixing symbioses as well as engineering plant resistance or tolerance to RKN. The quest for engineering nonlegumes to enable the formation of new nitrogen-fixing symbioses has, so far, not been realized, as nodulation requires the complex interaction of many genes controlling rhizosphere signaling, infection, defense, development, and nutrient exchange. Several recent discoveries about the possible origin of nodulation, its similarity to other root development processes, and the distinction between Nod factor and PAMP signaling has brought us closer to nodulating nonlegume crops (Geurts et al. 2016; Pankievicz et al. 2019). From the studies reviewed here, we predict that it would be unlikely that introducing nitrogen fixation into nonlegumes would exacerbate infection by RKN, as most studies have shown a protective effect of rhizobia on RKN infection (Table 2). However, initial controlled field evaluations with effective inoculants as well as native rhizobia would be advisable (Table 4).

Introducing RKN resistance genes into crops has often been unsuccessful and might reduce nodulation because of the strong defense and cell-death responses occurring (Goverse and Smant 2014), although this would need to be tested in RKN-resistant legumes (Table 4). Studies in legumes resistant to Phytophthora pathogens showed that higher resistance was associated with lower nodulation (Plett et al. 2016). In RKN-infested fields, where resistant cowpea plants containing the $R k$ gene are successively cultivated, virulent nematode populations develop after a few generations and overcome resistance (Petrillo et al. 2006). In fact, virulence acquisition in $\mathrm{RKN}$ populations under selective pressure by a resistant host has been described also for tomato and tomato rootstocks containing the RKN-resistance Mi gene (Verdejo-Lucas et al. 2009). Introducing other mechanisms of resistance, e.g., loss of susceptibility or tolerance to RKN (de Almeida Engler et al. 2005), would be an alternative 
strategy and its interaction with nodulation would depend on the tolerance mechanism. None of the genes or pathways listed in Table 3 would be ideal targets for reducing RKN susceptibility, as no mutation reduced galling without a negative effect on nodulation. The only exception was the reduced RKN susceptibility in the ethylene-sensitive, hypernodulating $s k l \mathrm{mu}-$ tant, but that mutant is hyperinfected by other pathogens (Penmetsa et al. 2008). Ideally, targeting either production of (rhizosphere) signals or proteins that specifically affect RKN viability or motility (Desmedt et al. 2020), perception, and response to ascarosides (Manohar et al. 2020), identifying specific immune targets of RKN effectors or expression of double stranded RNA against nematode-specific effector genes (Banerjee et al. 2017) might provide opportunities to reduce RKN infection without major negative effects on nodulation.

\section{LITERATURE CITED}

Adam, M., Heuer, H., and Hallmann, J. 2014. Bacterial antagonists of fungal pathogens also control root-knot nematodes by induced systemic resistance of tomato plants. PLoS One 9:e90402.

Aguilar, J. M. M., Ashby, A. M., Richards, A. J. M., Loake, G. J., Watson, M. D., and Shaw, C. H. 1988. Chemotaxis of Rhizobium legminosarum biovar phaseoli towards flavonoid inducers of the symbiotic nodulation genes. J. Gen. Microbiol. 134:2741-2746.

Ahmed, A. Q., Javed, N., Khan, S. A., and Abbas, H. M. K. 2016. Efficacy of rhizospheric organism Rhizobium leguminosarum against Meloidogyne incognita in soybean. Pak. J. Agric. Sci. 53:377-381.

Akhtar, M. S., and Siddiqui, Z. A. 2008. Biocontrol of a root-rot disease complex of chickpea by Glomus intraradices, Rhizobium sp. and Pseudomonas straita. Crop Prot. 27:410-417.

Ali, M. A., Trabulsi, I. Y., and Abd-Elsamea, M. E. 1981. Antagonisitic interaction between Meloidogyne incognita and Rhizobium leguminosarum on cowpea. Plant Dis. 65:432-435.

Amor, B. B., Shaw, S. L., Oldroyd, G. E., Maillet, F., Penmetsa, R. V., Cook, D., Long, S. R., Dénarié, J., and Gough, C. 2003. The NFP locus of Medicago truncatula controls an early step of Nod factor signa transduction upstream of a rapid calcium flux and root hair deformation. Plant J. 34:495-506.

Andrén, O., Bengtsson, J., and Clarholm, M. 1995. Biodiversity and species redundancy among litter decomposers. Pages 141-151 in: The Significance and Regulation of Soil Biodiversity. Developments in Plant and Soil Sciences. H. P. Collins, G. P. Robertson, and M. J. Klug, eds Vol. 63. Springer, Dordrecht, Netherlands.

Anver, S., and Alam, M. M. 1999. Control of Meloidogyne incognita and Rotylenchulus reniformis singly and concomitantly on chickpea and pigeonpea. Arch.Phytopathol. Plant Prot. 32:161-172.

Arnold, M. F. F., Penterman, J., Shabab, M., Chen, E. J., and Walker, G. C 2018. Important late-stage symbiotic role of the Sinorhizobium meliloti exopolysaccharide succinoglycan. J. Bacteriol. 200:e00665-17.

Arrighi, J. F., Barre, A., Ben Amor, B., Bersoult, A., Soriano, L. C., Mirabella, R., de Carvalho-Niebel, F., Journet, E. P., Gherardi, M., Huguet, T., Geurts, R., Denarie, J., Rouge, P., and Gough, C. 2006. The Medicago truncatula lysine motif-receptor-like kinase gene family includes NFP and new nodule-expressed genes. Plant Physiol. 142:265-279.

Baier, M. C., Barsch, A., Küster, H., and Hohnjec, N. 2007. Antisense repression of the Medicago truncatula nodule-enhanced sucrose synthase leads to a handicapped nitrogen fixation mirrored by specific alterations in the symbiotic transcriptome and metabolome. Plant Physiol. 145:1600-1618.

Baldwin, J. G., Nadler, S. A., and Adams, B. J. 2004. Evolution of plant parasitism among nematodes. Annu. Rev. Phytopathol. 42:83-105.

Banerjee, S., Banerjee, A., Gill, S. S., Gupta, O. P., Dahuja, A., Jain, P. K., and Sirohi, A. 2017. RNA Interference: A novel source of resistance to combat plant parasitic nematodes. Front. Plant Sci. 8:834

Barcala, M., García, A., Cabrera, J., Casson, S., Lindsey, K., Favery, B., García-Casado, G., Solano, R., Fenoll, C., and Escobar, C. 2010. Early transcriptomic events in microdissected Arabidopsis nematode-induced giant cells. Plant J. 61:698-712.

Barker, K. R., and Hussey, R. S. 1976. Histopathology of nodular tissues of legumes infected with certain nematodes. Phytopathol. 66:851-855.

Bartlem, D. G., Jones, M. G., and Hammes, U. Z. 2014. Vascularization and nutrient delivery at root-knot nematode feeding sites in host roots. J. Exp. Bot. 65:1789-1798.
Beale, E., Li, G., Tan, M. W., and Rumbaugh, K. P. 2006. Caenorhabditis elegans senses bacterial autoinducers. Appl. Environ. Microbiol. 72: 5135-5137.

Benková, E., Michniewicz, M., Sauer, M., Teichmann, T., Seifertova, D., Jurgens, G., and Friml, J. 2003. Local, efflux-dependent auxin gradients as a common module for plant organ formation. Cell 115:591-602.

Bhattarai, K. K., Xie, Q. G., Mantelin, S., Bishnoi, U., Girke, T., Navarre, D. A., and Kaloshian, I. 2008. Tomato susceptibility to root-knot nematodes requires an intact jasmonic acid signaling pathway. Mol. Plant-Microbe Interact. 21:1205-1214.

Bhuvaneswari, T. V., Bhagwat, A. A., and Bauer, W. D. 1981. Transient susceptibility of roo cells in four common legumes to nodulation by rhizobia. Plant Physiol. 68:1144-1149.

Bird, D. M., and Kaloshian, I. 2003. Are root special? Nematodes have their say. Physiol. Mol. Plant Pathol. 62:115-123.

Bopaiah, B. M., Patil, R. B., and Reddy, D. D. R. 1976. Effect of Meloidogyne javanica on nodulation and symbiotic nitrogen fixation in mung, Vigna radiata. Indian J. Nematol. 6:124-130.

Bozsoki, Z., Gysel, K., Hansen, S. B., Lironi, D., Krönauer, C., Feng, F., de Jong, N., Vinther, M., Kamble, M., Thygesen, M. B., Engholm, E., Kofoed, C., Fort, S., Sullivan, J. T., Ronson, C. W., Jensen, K. J., Blaise, M., Oldroyd, G., Stougaard, J., Andersen, K. R., and Radutoiu, S. 2020. Ligand-recognizing motifs in plant LysM receptors are major determinants of specificity. Science 369:663-670.

Bright, L. J., Liang, Y., Mitchell, D. M., and Harris, J. M. 2005. The LATD gene of Medicago truncatula is required for both nodule and roo development. Mol. Plant-Microbe Interact. 18:521-532.

Butcher, R. A., Ragains, J. R., Li, W., Ruvkun, G., Clardy, J., and Mak, H. Y. 2009. Biosynthesis of the Caenorhabditis elegans dauer pheromone. Proc. Natl. Acad. Sci. U.S.A. 106:1875-1879.

Cabello, S., Lorenz, C., Crespo, S., Cabrera, J., Ludwig, R., Escobar, C. and Hofmann, J. 2014. Altered sucrose synthase and invertase expression affects the local and systemic sugar metabolism of nematode-infected Arabidopsis thaliana plants. J. Exp. Bot. 65:201-212.

Cabrera, J., Fenoll, C., and Escobar, C. 2015. Genes co-regulated with $L B D 16$ in nematode feeding sites inferred from in silico analysis show similarities to regulatory circuits mediated by the auxin/cytokinin balance in Arabidopsis. Plant Signal. Behav. 10:e990825.

Castagnone-Sereno, P., Danchin, E. G., Perfus-Barbeoch, L., and Abad, P. 2013. Diversity and evolution of root-knot nematodes, genus Meloidogyne: New insights from the genomic era. Annu. Rev. Phytopathol. 51:203-220.

Čepulyte, R., Danquah, W. B., Bruening, G., and Williamson, V. M. 2018. Potent attractant for root-knot nematodes in exudates from seedling root tips of two host species. Sci. Rep. 8:10847.

Chahal, P., and Chahal, V. 1988. Interaction of Rhizobium and Meloidogyne incognita on symbiotic nitrogen fixation in mungbean under different concentrations of iron. J. Plant Nutr. 11:821-828.

Chahal, P., and Chahal, V. 1988. Effects of different population levels of Meloidogyne incognita on nitrogenase activity, leghaemoglobin and bacteroid contents of chickpea (Cicer arietinum L.) nodules formed by Rhizobium spp. Zentralbl. Mikrobiol. 143:63-65.

Chin, S., Behm, C. A., and Mathesius, U. 2018. Functions of flavonoids in plant-nematode interactions. Plants 7:85

Choe, A., von Reuss, S. H., Kogan, D., Gasser, R. B., Platzer, E. G. Schroeder, F. C., and Sternberg, P. W. 2012. Ascaroside signaling is widely conserved among nematodes. Curr. Biol. 22:772-780.

Clarke, V. C., Loughlin, P. C., Day, D. A., and Smith, P. M. 2014. Transport processes of the legume symbiosome membrane. Front. Plant Sci. 5:699.

Concha, C., and Doerner, P. 2020. The impact of the rhizobia-legume symbiosis on host root system architecture. J. Exp. Bot. 71:3902-3921.

Costa, S. R., Chin, S., and Mathesius, U. 2020. Infection of Medicago truncatula by the root-knot nematode Meloidogyne javanica does not require early nodulation genes. Front. Plant Sci. 11:1050.

Couëdel, A., Kirkegaard, J., Alletto, L., and Justes, E. 2019. Cruciferlegume cover crop mixtures for biocontrol: Towards a new multi-service paradigm. Adv. Agron. 157:55-139.

Curtis, R. H. C. 2007. Do phytohormones influence nematode invasion and feeding site establishment? Nematol. 9:155-160.

Curtis, R. H. C. 2008. Plant-nematode interactions: Environmental signals detected by the nematode's chemosensory organs control changes in the surface cuticle and behaviour. Soc. Franc. Parasitol. 15:310-316.

Damiani, I., Baldacci-Cresp, F., Hopkins, J., Andrio, E., Balzergue, S., Lecomte, P., Puppo, A., Abad, P., Favery, B., and Herouart, D. 2012 Plant genes involved in harbouring symbiotic rhizobia or pathogenic nematodes. New Phytol. 194:511-522.

Das, S., DeMason, D. A., Ehlers, J. D., Close, T. J., and Roberts, P. A. 2008. Histological characterization of root-knot nematode resistance in 
cowpea and its relation to reactive oxygen species modulation. J. Exp. Bot. 59:1305-1313.

Davies, K. G., and Curtis, R. H. 2011. Cuticle surface coat of plant-parasitic nematodes. Annu. Rev. Phytopathol. 49:135-156.

Davis, B. M., Jensen, R., Williams, P., and O'Shea, P. 2010. The interaction of $\mathrm{N}$-acylhomoserine lactone quorum sensing signaling molecules with biological membranes: Implications for inter-kingdom signaling. PLoS One 5:e13522.

de Almeida Engler, J., Favery, B., Engler, G., and Abad, P. 2005. Loss of susceptibility as an alternative for nematode resistance. Curr. Opin. Biotechnol. 16:112-117.

de Almeida Engler, J., and Gheysen, G. 2013. Nematode-induced endoreduplication in plant host cells: Why and how? Mol. PlantMicrobe Interact. 26:17-24.

de Almeida Engler, J., Kyndt, T., Vieira, P., Van Cappelle, E., Boudolf, V., Sanchez, V., Escobar, C., De Veylder, L., Engler, G., Abad, P., and Gheysen, G. 2012. CCS52 and DEL1 genes are key components of the endocycle in nematode-induced feeding sites. Plant J. 72:185-198.

de Billy, F., Grosjean, C., May, S., Bennett, M., and Cullimore, J. V. 2001. Expression studies on AUX1-like genes in Medicago truncatula suggest that auxin is required at two steps in early nodule development. Mol. Plant-Microbe Interact. 14:267-277.

De Meutter, J., Tytgat, T., Prinsen, E., Gheysen, G., Van Onckelen, H., and Gheysen, G. 2005. Production of auxin and related compounds by the plant parasitic nematodes Heterodera schachtii and Meloidogyne incognita. Commun. Agric. Appl. Biol. Sci. 70:51-60.

De Meutter, J., Tytgat, T., Witters, E., Gheysen, G., Van Onckelen, H., and Gheysen, G. 2003. Identification of cytokinins produced by the plant parasitic nematodes Heterodera schachtii and Meloidogyne incognita. Mol. Plant Pathol. 4:271-277.

Deakin, W. J., and Broughton, W. J. 2009. Symbiotic use of pathogenic strategies: Rhizobial protein secretion systems. Nat. Rev. Microbiol. 7:312-320.

Desaeger, J., Odee, D., Machua, J., and Esitubi, M. 2005. Interactions between Meloidogyne javanica (Treub) chitwood and rhizobia on growth of Sesbania sesban (L.). Merr. Appl. Soil Ecol. 29:252-258.

Desmedt, W., Mangelinckx, S., Kyndt, T., and Vanholme, B. 2020. A phytochemical perspective on plant defense against nematodes. Front. Plant Sci. 11:602079.

Dharmatilake, A. J., and Bauer, W. D. 1992. Chemotaxis of Rhizobium meliloti towards nodulation gene inducing compounds from alfalfa roots. Appl. Environ. Microbiol. 58:1153-1158.

Diaz, S. A., Brunet, V., Lloyd-Jones, G. C., Spinner, W., Wharam, B., and Viney, M. 2014. Diverse and potentially manipulative signalling with ascarosides in the model nematode $C$. elegans. BMC Evol. Biol. 14:46.

Dong, W., Zhu, Y., Chang, H., Wang, C., Yang, J., Shi, J., Gao, J., Yang, W., Lan, L., Wang, Y., Zhang, X., Dai, H., Miao, Y., Xu, L., He, Z., Song, C., Wu, S., Wang, D., Yu, N., and Wang, E. 2020. An SHR-SCR module specifies legume cortical cell fate to enable nodulation. Nature 589 : 586-590.

Dowd, C. D., Chronis, D., Radakovic, Z. S., Siddique, S., Schmülling, T., Werner, T., Kakimoto, T., Grundler, F. M. W., and Mitchum, M. G. 2017 Divergent expression of cytokinin biosynthesis, signaling and catabolism genes underlying differences in feeding sites induced by cyst and rootknot nematodes. Plant J. 92:211-228.

Doyle, E. A., and Lambert, K. N. 2003. Meloidogyne javanica chorismate mutase 1 alters plant cell development. Mol. Plant-Microbe Interact. 16: 123-131.

Doyle, J. J. 2011. Phylogenetic perspectives on the origins of nodulation Mol. Plant-Microbe Interact. 24:1289-1295.

Duponnois, R., Cadet, P., Senghor, K., and Sougoufara, B. 1997. Sensibilité de plusieurs acacias australiens au nématode à galles Meloidogyne javanica. Ann. Sci. For. 54:181-190.

Duponnois, R., Neyra, M., Senghor, K., and Bâ, A. 1999a. Effects of the root-knot nematode Meloidogyne javanica on the symbiotic relationships between different strains of Rhizobia and Acacia holosericea (A Cunn. ex G. Don). Eur. J. Soil Biol. 35:99-105.

Duponnois, R., Senghor, K., Thoulouse, J., and Bâ, A. M. 1999. Susceptibility of several sahelian Acacia to Meloidogyne javanica (Treub) Chitw. Agrofor. Syst. 46:123-130.

El-Bahrawy, S. A., and Salem, F. M. 1989. Interaction between Rhizobium leguminosarum and Meloidogyne javanica nematode in broad bean under nematicide application. Zentralbl. Mikrobiol. 144:279-281.

El-Shafeey, I. E., Abd-El-Hadi, M. A., Hagag, E. S., and El-Naga, G. S. A. 2019. Utilization of organic and bio fertilizers against root-knot nematode (Meloidogyne incognita) infecting faba bean (Vicia faba L.). Bulg. J. Agric. Sci. 25:506-513.

El Yahyaoui, F., Küster, H., Ben Amor, B., Hohnjec, N., Pühler, A., Becker, A., Gouzy, J., Vernié, T., Gough, C., Niebel, A., Godiard, L., and Gamas,
P. 2004. Expression profiling in Medicago truncatula identifies more than 750 genes differentially expressed during nodulation, including many potential regulators of the symbiotic program. Plant Physiol. 136: 3159-3176.

Evans, J. R., and Clarke, V. C. 2019. The nitrogen cost of photosynthesis. J. Exp. Bot. 70:7-15.

Fazal, M., Siddiqui, Z. A., and Imran, M. 1992. Effect of pre-, post- and simultaneous inoculations of Rhizobium, Rotylenchus reniformis and Meloidogyne incognita on lentil. Nematol. Mediterr. 20:159-161.

Ferguson, B. J., and Mathesius, U. 2014. Phytohormone regulation of legume-rhizobia interactions. J. Chem. Ecol. 40:770-790.

Ferguson, B. J., Mens, C., Hastwell, A. H., Zhang, M., Su, H., Jones, C. H., Chu, X., and Gresshoff, P. M. 2019. Legume nodulation: The host controls the party. Plant Cell Environ. 42:41-51.

Fery, R. L., and Dukes, P. D. 1980. Inheritance of root-knot resistance in the cowpea (Vigna unguiculata (L.) Walp.). J. Am. Horticult. Soc. 105: 671-674.

Fustec, J., Lesuffleur, F., Mahieu, S., and Cliquet, J. B. 2010. Nitrogen rhizodeposition of legumes. A review. Agron. Sustain. Dev. 30:57-66.

Gage, D. J. 2004. Infection and invasion of roots by symbiotic, nitrogenfixing rhizobia during nodulation of temperate legumes. Microbiol. Mol Biol. Rev. 68:280-300.

Gaudin, A. C. M., Westra, S., Loucks, C. E. S., Janovicek, K., Martin, R. C., and Deen, W. 2013. Improving resilience of northern field crop systems using inter-seeded red clover: A review. Agron. 3:148-180.

Gauthier-Coles, C., White, R. G., and Mathesius, U. 2018. Nodulating legumes are distinguished by a sensitivity to cytokinin in the root cortex leading to pseudonodule development. Front. Plant Sci. 9:1901.

Geurts, R., Xiao, T. T., and Reinhold-Hurek, B. 2016. What does it take to evolve a nitrogen-fixing endosymbiosis? Trends Plant Sci. 21:199-208

Gheysen, G., and Mitchum, M. G. 2011. How nematodes manipulate plant development pathways for infection. Curr. Opin. Plant Biol. 14:415-421.

Giraud, E., Moulin, L., Vallenet, D., Barbe, V., Cytryn, E., Avarre, J. C., Jaubert, M., Simon, D., Cartieaux, F., Prin, Y., Bena, G., Hannibal, L., Fardoux, J., Kojadinovic, M., Vuillet, L., Lajus, A., Cruveiller, S., Rouy, Z., Mangenot, S., Segurens, B., Dossat, C., Franck, W. L., Chang, W. S., Saunders, E., Bruce, D., Richardson, P., Normand, P., Dreyfus, B., Pignol, D., Stacey, G., Emerich, D., Vermeglio, A., Medigue, C., and Sadowsky, M. 2007. Legumes symbioses: Absence of Nod genes in photosynthetic bradyrhizobia. Science 316:1307-1312.

Goh, C. H., Nicotra, A. B., and Mathesius, U. 2019. Genes controlling legume nodule numbers affect phenotypic plasticity responses to nitrogen in the presence and absence of rhizobia. Plant Cell Environ 42:1747-1757.

Gordon, A. J., Minchin, F. R., James, C. L., and Komina, O. 1999. Sucrose synthase in legume nodules is essential for nitrogen fixation. Plant Physiol. 120:867-877.

Gourion, B., Berrabah, F., Ratet, P., and Stacey, G. 2015. Rhizobiumlegume symbioses: The crucial role of plant immunity. Trends Plant Sci. 20:186-194.

Goverse, A., Engler, J. D., Verhees, J., van der Krol, S., Helder, J., and Gheysen, G. 2000. Cell cycle activation by plant parasitic nematodes. Plant Mol. Biol. 43:747-761.

Goverse, A., and Smant, G. 2014. The activation and suppression of plant innate immunity by parasitic nematodes. Annu. Rev. Phytopathol. 52: 243-265.

Griesmann, M., Chang, Y., Liu, X., Song, Y., Haberer, G., Crook, M. B., Billault-Penneteau, B., Lauressergues, D., Keller, J., Imanishi, L. Roswanjaya, Y. P., Kohlen, W., Pujic, P., Battenberg, K., Alloisio, N., Liang, Y., Hilhorst, H., Salgado, M. G., Hocher, V., Gherbi, H., Svistoonoff, S., Doyle, J. J., He, S., Xu, Y., Xu, S., Qu, J., Gao, Q., Fang, X., Fu, Y., Normand, P., Berry, A. M., Wall, L. G., Ané, J. M., Pawlowski, K., Xu, X., Yang, H., Spannagl, M., Mayer, K. F. X., Wong, G. K., Parniske, M., Delaux, P. M., Cheng, S. 2018. Phylogenomics reveals multiple losses of nitrogen-fixing root nodule symbiosis. Science 361:eaat1743.

Hammes, U. Z., Schachtman, D. P., Berg, R. H., Nielsen, E., Koch, W. McIntyre, L. M., and Taylor, C. G. 2005. Nematode-induced changes of transporter gene expression in Arabidopsis roots. Mol. Plant-Microbe Interact. 18:1247-1257

Harris, J. M., Balint-Kurti, P., Bede, J. C., Day, B., Gold, S., Goss, E. M., Grenville-Briggs, L. J., Jones, K. M., Wang, A., Wang, Y., Mitra, R. M. Sohn, K. H., and Alvarez, M. E. 2020. What are the top 10 unanswered questions in molecular plant-microbe interactions? Mol. Plant-Microbe Interact. 33:1354-1365

Hartley, C. J., Lillis, P. E., Owens, R. A., and Griffin, C. T. 2019. Infective juveniles of entomopathogenic nematodes (Steinernema and Heterorhabditis) secrete ascarosides and respond to interspecific dispersal signals. J. Invertebr. Pathol. 168:107257. 
Hartmann, A., Rothballer, M., Hense, B. A., and Schröder, P. 2014. Bacterial quorum sensing compounds are important modulators of microbe-plant interactions. Front. Plant Sci. 5:131.

Hassan, S., and Mathesius, U. 2012. The role of flavonoids in rootrhizosphere signaling-Opportunities and challenges for improving plant-microbe interactions. J. Exp. Bot. 63:3429-3444.

Henkle-Dührsen, K., and Kampkötter, A. 2001. Antioxidant enzyme families in parasitic nematodes. Mol. Biochem. Parasitol. 114:129-142.

Herrbach, V., Chirinos, X., Rengel, D., Agbevenou, K., Vincent, R., Pateyron, S., Huguet, S., Balzergue, S., Pasha, A., Provart, N., Gough, C., and Bensmihen, S. 2017. Nod factors potentiate auxin signaling for transcriptional regulation and lateral root formation in Medicago truncatula. J. Exp. Bot. 68:569-583.

Herridge, D. F., Peoples, M. B., and Boddey, R. M. 2008. Global inputs of biological nitrogen fixation in agricultural systems. Plant Soil 311:1-18.

Holbein, J., Franke, R. B., Marhavý, P., Fujita, S., Górecka, M., Sobczak, M., Geldner, N., Schreiber, L., Grundler, F. M. W., and Siddique, S. 2019. Root endodermal barrier system contributes to defence against plant-parasitic cyst and root-knot nematodes. Plant J. 100:221-236.

Hollister, K. A., Conner, E. S., Zhang, X., Spell, M., Bernard, G. M., Patel, P., de Carvalho, A. C., Butcher, R. A., and Ragains, J. R. 2013. Ascaroside activity in Caenorhabditis elegans is highly dependent on chemical structure. Bioorg. Med. Chem. 21:5754-5769.

Holterman, M., Karssen, G., van den Elsen, S., van Megen, H., Bakker, J., and Helder, J. 2009. Small subunit rDNA-based phylogeny of the Tylenchida sheds light on relationships among some high-impact plant-parasitic nematodes and the evolution of plant feeding. Phytopathol. 99:227-235.

Huo, X. Y., Schnabel, E., Hughes, K., and Frugoli, J. 2006. RNAi phenotypes and the localization of a protein: GUS fusion imply a role for Medicago truncatula PIN genes in nodulation. J. Plant Growth Regul 25:156-165.

Hussaini, S. S., and Seshadri, A. R. 1975. Interrelationships between Meloidogyne incognita and Rhizobium sp on mung bean (Phaeolus aureus). Indian J. Nematol. 5:189-199.

Hussey, R. S., and Barker, K. R. 1976. Influence of nematodes and light sources on growth and nodulation of soybean. Paper no. 4672. The North Carolina Agricultural Experiment Station, Raleigh, N. C., U.S.A.

Hutangura, P., Mathesius, U., Jones, M. G. K., and Rolfe, B. G. 1999. Auxin induction is a trigger for root gall formation caused by root-knot nematodes in white clover and is associated with the activation of the flavonoid pathway. Aust. J. Plant Physiol. 26:221-231.

Izuogu, N. B., Olajide, T. U., Eifediyi, E. K., and Olajide, C. M. 2019 Effect of root-knot nematode (Meloidogyne incognita) on the nodulation of some varieties of cowpea (Vigna unguiculata L. Walp). Sci. Agric. Bohem. 50:104-109.

Jahoor, A., Patel, R., Bryan, A., Do, C., Krier, J., Watters, C., Wahli, W., Li, G., Williams, S. C., and Rumbaugh, K. P. 2008. Peroxisome proliferatoractivated receptors mediate host cell proinflammatory responses to Pseudomonas aeruginosa autoinducer. J. Bacteriol. 190:4408-4415.

Jammes, F., Lecomte, P., de Almeida-Engler, J., Bitton, F., MartinMagniette, M. L., Renou, J. P., Abad, P., and Favery, B. 2005. Genomewide expression profiling of the host response to root-knot nematode infection in Arabidopsis. Plant J. 44:447-458.

Jeong, P. Y., Jung, M., Yim, Y. H., Kim, H., Park, M., Hong, E., Lee, W. Kim, Y. H., Kim, K., and Paik, Y. K. 2005. Chemical structure and biological activity of the Caenorhabditis elegans dauer-inducing pheromone. Nature 433:541-545

Jones, J. T., Haegeman, A., Danchin, E. G., Gaur, H. S., Helder, J., Jones, M. G., Kikuchi, T., Manzanilla-López, R., Palomares-Rius, J. E., Wesemael, W. M., and Perry, R. N. 2013. Top 10 plant-parasitic nematodes in molecular plant pathology. Mol. Plant Pathol. 14:946-961.

Jones, K. M., Sharopova, N., Lohar, D. P., Zhang, J. Q., VandenBosch, K. A., and Walker, G. C. 2008. Differential response of the plant Medicago truncatula to its symbiont Sinorhizobium meliloti or an exopolysaccharide-deficient mutant. Proc. Natl. Acad. Sci. U.S.A. 105: 704-709.

Jones, M. G. K. 1981. Host-cell responses to endo-parasitic nematode attack-Structure and function of giant-cells and syncytia. Ann. Appl. Biol. 97:353-372

Kaló, P., Gleason, C., Edwards, A., Marsh, J., Mitra, R. M., Hirsch, S. Jakab, J., Sims, S., Long, S. R., Rogers, J., Kiss, G. B., Downie, J. A., and Oldroyd, G. E. 2005. Nodulation signaling in legumes requires NSP2, a member of the GRAS family of transcriptional regulators. Science 308: 1786-1789.

Kaplan, F., Alborn, H. T., von Reuss, S. H., Ajredini, R., Ali, J. G., Akyazi, F., Stelinski, L. L., Edison, A. S., Schroeder, F. C., and Teal, P. E. 2012 Interspecific nematode signals regulate dispersal behavior. PLoS One 7 : e38735.
Karczmarek, A., Overmars, H., Helder, J., and Goverse, A. 2004. Feeding cell development by cyst and root-knot nematodes involves a similar early, local and transient activation of a specific auxin-inducible promoter element. Mol. Plant Pathol. 5:343-346.

Karlsson, T., Turkina, M. V., Yakymenko, O., Magnusson, K. E., and Vikstrom, E. 2012. The Pseudomonas aeruginosa $N$-acylhomoserine lactone quorum sensing molecules target IQGAP1 and modulate epithelial cell migration. PLoS Pathog. 8:e1002953.

Kelly, S., Mun, T., Stougaard, J., Ben, C., and Andersen, S. U. 2018. Distinct Lotus japonicus transcriptomic responses to a spectrum of bacteria ranging from symbiotic to pathogenic. Front. Plant Sci. 9: 1218.

Khan, M. R., and Khan, M. W. 1996. Development of root-knot and rootnodules on cowpea as influenced by sulphur dioxide. Nematol. Mediterr. 24:33-35.

Khan, M. R., Kounsar, K., and Hamid, A. 2002. Effect of certain rhizobacteria and antagonistic fungi on root-nodulation and root-knot nematode disease of green gram. Nematol. Mediterr. 30:85-89.

Khan, M. R., Mohiddin, F. A., and Ahamad, F. 2018. Inoculant rhizobia suppressed root-knot disease, and enhanced plant productivity and nutrient uptake of some field-grown food legumes. Acta Agric. Scand. B Soil Plant Sci. 68:166-174.

Khan, M. W., and Salam, M. A. 1990. Interactions of Meloidogyne javanica, Fusarium udum and Rhizobium on pigeon pea in the presence of nickel and cobalt as pollutants. Ann. Appl. Biol. 116:549-556.

Khan, T. A., and Husain, S. I. 1988. Effects of individual, concomitant and sequential inoculations of Rhizobium, Rotylenchus reniformis, Meloidogyne incognita and Rhizoctonia solani on cowpea plant growth, disease development and nematode multiplication. Indian J. Nematol. 18 232-238.

Kiers, E. T., and Denison, R. F. 2008. Sanctions, cooperation, and the stability of plant-rhizosphere mutualisms. Annu. Rev. Ecol. Evol. Syst 39:215-236.

Kim, K., Sato, K., Shibuya, M., Zeiger, D. M., Butcher, R. A., Ragains, J. R., Clardy, J., Touhara, K., and Sengupta, P. 2009. Two chemoreceptors mediate developmental effects of dauer pheromone in C. elegans. Science 326:994-998

Klessig, D. F., Mahonar, M., Baby, S., Koch, A., Danquah, W. B., Luna, E., Park, H. J., Kolkman, J. M., Turgeon, B. G., Nelson, R., Leach, J. E., Williamson, V. M., Kogel, K. H., Kachroo, A., and Schroeder, F. C. 2019. Nematode ascaroside enhances resistance in a broad spectrum of plant-pathogen systems. J. Phytopathol. 167:265-272.

Knox, O. G., Killham, K., Artz, R. R., Mullins, C., and Wilson, M. 2004 Effect of nematodes on rhizosphere colonization by seed-applied bacteria. Appl. Environ. Microbiol. 70:4666-4671.

Kohlen, W., Ng, J. L. P., Deinum, E. E., and Mathesius, U. 2018. Auxin transport, metabolism, and signalling during nodule initiation: Indeterminate and determinate nodules. J. Exp. Bot. 69:229-244.

Koltai, H., Dhandaydham, M., Opperman, C., Thomas, J., and Bird, D. 2001. Overlapping plant signal transduction pathways induced by a parasitic nematode and a rhizobial endosymbiont. Mol. Plant-Microbe Interact. 14:1168-1177.

Kouchi, H., Shimomura, K., Hata, S., Hirota, A., Wu, G. J., Kumagai, H., Tajima, S., Suganuma, N., Suzuki, A., Aoki, T., Hayashi, M., Yokoyama, T., Ohyama, T., Asamizu, E., Kuwata, C., Shibata, D., and Tabata, S 2004. Large-scale analysis of gene expression profiles during early stages of root nodule formation in a model legume, Lotus japonicus DNA Res. 11:263-274.

Kryvoruchko, I. S., Sinharoy, S., Torres-Jerez, I., Sosso, D., Pislariu, C. I., Guan, D., Murray, J., Benedito, V. A., Frommer, W. B., and Udvardi, M. K. 2016. MtSWEET11, a nodule-specific sucrose transporter of Medicago truncatula. Plant Physiol. 171:554-565.

Kyndt, T., Goverse, A., Haegeman, A., Warmerdam, S., Wanjau, C., Jahani, M., Engler, G., de Almeida Engler, J., and Gheysen, G. 2016. Redirection of auxin flow in Arabidopsis thaliana roots after infection by root-knot nematodes. J. Exp. Bot. 67:4559-4570.

Liang, Y., and Harris, J. M. 2005. Response of root branching to abscisic acid is correlated with nodule formation both in legumes and nonlegumes. Am. J. Bot. 92:1675-1683

Liu, C. W., and Murray, J. D. 2016. The role of flavonoids in nodulation host-range specificity: An update. Plants 5:33.

Liu, J., and Bisseling, T. 2020. Evolution of NIN and NIN-like genes in relation to nodule symbiosis. Genes (Basel) 11:777.

Liu, J., Rutten, L., Limpens, E., van der Molen, T., van Velzen, R., Chen, R., Chen, Y., Geurts, R., Kohlen, W., Kulikova, O., and Bisseling, T. 2019. A remote cis-regulatory region is required for $N I N$ expression in the pericycle to initiate nodule primordium formation in Medicago truncatula. Plant Cell 31:68-83. 
Lohar, D. P., and Bird, D. M. 2003. Lotus japonicus: A new model to study root-parasitic nematodes. Plant Cell Physiol. 44:1176-1184.

Lohar, D. P., Schaff, J. E., Laskey, J. G., Kieber, J. J., Bilyeu, K. D., and Bird, D. M. 2004. Cytokinins play opposite roles in lateral root formation, and nematode and rhizobial symbioses. Plant J. 38:203-214.

Lopez-Gomez, M., Sandal, N., Stougaard, J., and Boller, T. 2012. Interplay of flg22-induced defence responses and nodulation in Lotus japonicus. J. Exp. Bot. 63:393-401.

Malek, R., and Jenkins, W. 1967. Aspects of the host-parasite relationships of nematodes and hairy vetch. Bulletin no. 813. New Jersey Agricultural Experiment Station, New Brunswick, NJ, U.S.A.

Manohar, M., Tenjo-Castano, F., Chen, S., Zhang, Y. K., Kumari, A., Williamson, V. M., Wang, X., Klessig, D. F., and Schroeder, F. C. 2020. Plant metabolism of nematode pheromones mediates plant-nematode interactions. Nat. Commun. 11:208.

Manosalva, P., Manohar, M., von Reuss, S. H., Chen, S., Koch, A., Kaplan, F., Choe, A., Micikas, R. J., Wang, X., Kogel, K. H., Sternberg, P. W. Williamson, V. M., Schroeder, F. C., and Klessig, D. F. 2015. Conserved nematode signalling molecules elicit plant defenses and pathogen resistance. Nat. Commun. 6:7795.

Mapope, N., and Dakora, F. D. 2013. Role of flavonoid and isoflavonoid molecules in symbiotic functioning and host-plant defense in the Leguminosae. Pages 33-48 in: The Chemistry for Sustainable Development in Africa. Gurib-Fakim, A., and Eloff, J., eds. Springer, Berlin.

Maróti, G., Downie, J. A., and Kondorosi, É. 2015. Plant cysteine-rich peptides that inhibit pathogen growth and control rhizobial differentiation in legume nodules. Curr. Opin. Plant Biol. 26:57-63.

Marsh, J. F., Rakocevic, A., Mitra, R. M., Brocard, L., Sun, J., Eschstruth, A., Long, S. R., Schultze, M., Ratet, P., and Oldroyd, G. E. 2007. Medicago truncatula NIN is essential for rhizobial-independent nodule organogenesis induced by autoactive calcium/calmodulin-dependent protein kinase. Plant Physiol. 144:324-335.

Martínez-Abarca, F., Herrera-Cervara, J. A., Bueno, P., Sanjuan, J. Bisseling, T., and Olivares, J. 1998. Involvement of salicylic acid in the establishment of the Rhizobium meliloti-alfalfa symbiosis. Mol. Plant-Microbe Interact. 11:153-155.

Mashela, P., and Pofu, K. 2012. Interactive effects of Meloidogyne incognita race 2, Bradyrhizobium japonicum and crude extracts of Cucumis myriocarpus fruit on Vigna unguiculata. Crop Prot. 40:69-72.

Masson-Boivin, C., Giraud, E., Perret, X., and Batut, J. 2009. Establishing nitrogen-fixing symbiosis with legumes: How many rhizobium recipes? Trends Microbiol. 17:458-466.

Mathesius, U. 2003. Conservation and divergence of signalling pathways between roots and soil microbes - the Rhizobium-legume symbiosis compared to the development of lateral roots, mycorrhizal interactions and nematode-induced galls. Plant Soil 255:105-119.

Mathesius, U., Mulders, S., Gao, M., Teplitski, M., Caetano-Anolles, G., Rolfe, B. G., and Bauer, W. D. 2003. Extensive and specific responses of a eukaryote to bacterial quorum-sensing signals. Proc. Natl. Acad. Sci. U.S.A. 100:1444-1449.

McSorley, R. 1999. Host suitability of potential cover crops for root-knot nematodes. Suppl. J. Nematol. 31:619-623.

Mejias, J., Truong, N. M., Abad, P., Favery, B., and Quentin, M. 2019. Plant proteins and processes targeted by parasitic nematode effectors. Front. Plant Sci. 10:970.

Menéndez, E., Robledo, M., Jiménez-Zurdo, J. I., Velázquez, E., Rivas, R., Murray, J. D., and Mateos, P. F. 2019. Legumes display common and host-specific responses to the rhizobial cellulase CelC2 during primary symbiotic infection. Sci. Rep. 9:13907.

Miyata, K., Kawaguchi, M., and Nakagawa, T. 2013. Two distinct EIN2 genes cooperatively regulate ethylene signaling in Lotus japonicus. Plant Cell Physiol. 54:1469-1477.

Moens, M., Perry, R. N., and Starr, J. L. 2009. Meloidogyne species - a diverse group of novel and important plant parasites. Pages 1-17 in: Root Knot Nematodes. R. Perry, M. Moens, and J. L. Starr, eds. CABI Publishing, Wallingford, U.K.

Moreau, S., Verdenaud, M., Ott, T., Letort, S., de Billy, F., Niebel, A., Gouzy, J., de Carvalho-Niebel, F., and Gamas, P. 2011. Transcription reprogramming during root nodule development in Medicago truncatula. PLoS One 6:e16463.

Murray, J. D. 2011. Invasion by invitation: Rhizobial infection in legumes. Mol. Plant-Microbe Interact. 24:631-639.

Murray, J. D., Karas, B. J., Sato, S., Tabata, S., Amyot, L., and Szczyglowski, K. 2007. A cytokinin perception mutant colonized by Rhizobium in the absence of nodule organogenesis. Science 315:101-104.

Ng, J. L. P., Welvaert, A., Wen, J., Chen, R., and Mathesius, U. 2020. The Medicago truncatula PIN2 auxin transporter mediates basipetal auxin transport but is not necessary for nodulation. J. Exp. Bot. 71:1562-1573.
Nicol, J. M., Turner, S. J., Coyne, D. L., den Nijs, L., Hockland, S., and Tahna Maafi, Z. 2011. Current nematode threats to world agriculture. Pages 21-43 in: Genomics and Molecular Genetics of Plant-Nematode Interactions. J. Jones, G. Gheysen, and C. Fenoll, eds. Springer, Dordrecht, Netherlands.

Nigh, E. 1966. Rhizobium nodule formation on alfalfa as influenced by Meloidogyne javanica. Nematol. 12:96.

Nishimura, R., Hayashi, M., Wu, G. J., Kouchi, H., Imaizumi-Anraku, H., Murakami, Y., Kawasaki, S., Akao, S., Ohmori, M., Nagasawa, M., Harada, K., and Kawaguchi, M. 2002. HAR1 mediates systemic regulation of symbiotic organ development. Nature 420:426-429.

Niu, J., Liu, P., Liu, Q., Chen, C., Guo, Q., Yin, J., Yang, G., and Jian, H. 2016. Msp40 effector of root-knot nematode manipulates plant immunity to facilitate parasitism. Sci. Rep. 6:19443.

Oldroyd, G. E., and Downie, J. A. 2008. Coordinating nodule morphogenesis with rhizobial infection in legumes. Annu. Rev. Plant Biol. 59: 519-546.

Olmo, R., Cabrera, J., Díaz-Manzano, F. E., Ruiz-Ferrer, V., Barcala, M., Ishida, T., García, A., Andrés, M. F., Ruiz-Lara, S., Verdugo, I., Pernas, M., Fukaki, H., Del Pozo, J. C., Moreno-Risueno, M., Kyndt, T., Gheysen, G., Fenoll, C., Sawa, S., and Escobar, C. 2020. Root-knot nematodes induce gall formation by recruiting developmental pathways of post-embryonic organogenesis and regeneration to promote transient pluripotency. New Phytol. 227:200-215.

Olmo, R., Cabrera, J., Moreno-Risueno, M. A., Fukaki, H., Fenoll, C., and Escobar, C. 2017. Molecular transducers from roots are triggered in Arabidopsis leaves by root-knot nematodes for successful feeding site formation: A conserved post-embryogenic de novo organogenesis program? Front. Plant Sci. 8:875.

Oono, R., Anderson, C. G., and Denison, R. F. 2011. Failure to fix nitrogen by non-reproductive symbiotic rhizobia triggers host sanctions that reduce fitness of their reproductive clonemates. Proc. Biol. Sci. 278: 2698-2703.

Palmer, A. G., Mukherjee, A., Stacy, D. M., Lazar, S., Ane, J. M., and Blackwell, H. E. 2016. Interkingdom responses to bacterial quorum sensing signals regulate frequency and rate of nodulation in legumerhizobia symbiosis. ChemBioChem 17:2199-2205.

Pankievicz, V. C. S., Irving, T. B., Maia, L. G. S., and Ané, J. M. 2019. Are we there yet? The long walk towards the development of efficien symbiotic associations between nitrogen-fixing bacteria and nonleguminous crops. BMC Biol. 17:99.

Parniske, M., Ahlborn, B., and Werner, D. 1991. Isoflavonoid-inducible resistance to the phytoalexin glyceollin in soybean rhizobia. J. Bacteriol 173:3432-3439.

Pate, J., and Gunning, B. 1972. Transfer cells. Annu. Rev. Plant Physiol. 23: 173-196.

Peix, A., Ramires-Bahena, M. H., Velasquez, E., and Bedmar, E. J. 2015 Bacterial associations with legumes. Crit. Rev. Plant Sci. 34:17-42.

Penmetsa, R. V., and Cook, D. R. 1997. A legume ethylene-insensitive mutant hyperinfected by its rhizobial symbiont. Science 275:527-530.

Penmetsa, R. V., Uribe, P., Anderson, J., Lichtenzveig, J., Gish, J. C., Nam, Y. W., Engstrom, E., Xu, K., Sckisel, G., Pereira, M., Baek, J. M., LopezMeyer, M., Long, S. R., Harrison, M. J., Singh, K. B., Kiss, G. B., and Cook, D. R. 2008. The Medicago truncatula ortholog of Arabidopsis EIN2, sickle, is a negative regulator of symbiotic and pathogenic microbial associations. Plant J. 55:580-595.

Pérez-Montaño, F., Guasch-Vidal, B., Gonzalez-Barroso, S., Lopez-Baena, F. J., Cubo, T., Ollero, F. J., Gil-Serrano, A. M., Rodriguez-Carvajal, M. A., Bellogin, R. A., and Espuny, M. R. 2011. Nodulation-geneinducing flavonoids increase overall production of autoinducers and expression of $\mathrm{N}$-acyl homoserine lactone synthesis genes in rhizobia. Res. Microbiol. 162:715-723.

Perry, R. 1997. Plant signals in nematode hatching and attraction. Pages 38-50 in: Cellular and molecular aspects of plant-nematode interactions C. Fenoll, F. Grundler, and S. Ohl, eds. Kluwer, Dordrecht.

Peters, N. K., Frost, J. W., and Long, S. R. 1986. The flavone, luteolin, induces expression of Rhizobium meliloti nodulation genes. Science 233 977-980.

Petrillo, M. D., Matthews, W. C., and Roberts, P. A. 2006. Dynamics of Meloidogyne incognita virulence to resistance genes $R k$ and $R k 2$ in cowpea. J. Nematol. 38:90-96.

Plet, J., Wasson, A., Ariel, F., Le Signor, C., Baker, D., Mathesius, U., Crespi, M., and Frugier, F. 2011. MtCRE1-dependent cytokinin signaling integrates bacterial and plant cues to coordinate symbiotic nodule organogenesis in Medicago truncatula. Plant J. 65:622-633.

Plett, J. M., Plett, K. L., Bithell, S. L., Mitchell, C., Moore, K., Powell, J. R., and Anderson, I. C. 2016. Improved Phytophthora resistance in commercial chickpea (Cicer arietinum) varieties negatively impacts 
symbiotic gene signalling and symbiotic potential in some varieties. Plant Cell Environ. 39:1858-1869.

Przybylska, A., and Obrępalska-Stęplowska, A. 2020. Plant defense responses in monocotyledonous and dicotyledonous host plants during root-knot nematode infection. Plant Soil 451:239-260.

Radutoiu, S., Madsen, L. H., Madsen, E. B., Felle, H. H., Umehara, Y., Gronlund, M., Sato, S., Nakamura, Y., Tabata, S., Sandal, N., and Stougaard, J. 2003. Plant recognition of symbiotic bacteria requires two LysM receptor-like kinases. Nature 425:585-592.

Rao, J. R., and Cooper, J. E. 1994. Rhizobia catabolize nod gene-inducing flavonoids via C-ring fission mechanisms. J. Bacteriol. 176:54095413.

Redmond, J. R., Batley, M., Djordjevic, M. A., Innes, R. W., Keumpel, P. L., and Rolfe, B. G. 1986. Flavones induce expression of nodulation genes in Rhizobium. Nature 323:632-635.

Richardson, L., and Price, N. S. 1984. Observation on the biology of Meloidogyne incognita and the diageotropica tomato mutant. Rev. Nematol. 7:97-99.

Roberts, P. A., Matthews, W. C., and Ehlers, J. D. 1996. New resistance to virulent root-knot nematodes linked to the Rk locus of cowpea. Crop Sci. 36:889-894.

Rodiuc, N., Vieira, P., Banora, M. Y., and de Almeida Engler, J. 2014. On the track of transfer cell formation by specialized plant-parasitic nematodes. Front. Plant Sci. 5:160.

Rodríguez-Navarro, D., Oliver, M., Contreras, A., and Ruiz-Sainz, J. 2011. Soybean interactions with soil microbes, agronomical and molecular aspects. Agron. Sustain. Dev. 31:173-190.

Roudier, F., Fedorova, E., Lebris, M., Lecomte, P., Györgyey, J., Vaubert, D., Horvath, G., Abad, P., Kondorosi, A., and Kondorosi, E. 2003. The Medicago species A2-type cyclin is auxin regulated and involved in meristem formation but dispensable for endoreduplication-associated developmental programs. Plant Physiol. 131:1091-1103.

Roy, S., Robson, F., Lilley, J., Liu, C. W., Cheng, X., Wen, J., Walker, S., Sun, J., Cousins, D., Bone, C., Bennett, M. J., Downie, J. A., Swarup, R., Oldroyd, G., and Murray, J. D. 2017. MtLAX2, a functional homologue of the Arabidopsis auxin influx transporter AUX1, is required for nodule organogenesis. Plant Physiol. 174:326-338.

Sanchez-Contreras, M., Bauer, W. D., Gao, M. S., Robinson, J. B., and Downie, J. A. 2007. Quorum-sensing regulation in rhizobia and its role in symbiotic interactions with legumes. Phil. Transact. Roy. Soc. B-Biol. Sci. 362:1149-1163.

Santi, C., Bogusz, D., and Franche, C. 2013. Biological nitrogen fixation in non-legume plants. Ann. Bot. 111:743-767.

Sato, K., Kadota, Y., and Shirasu, K. 2019. Plant immune responses to parasitic nematodes. Front. Plant Sci. 10:1165.

Schauser, L., Roussis, A., Stiller, J., and Stougaart, J. 1999. A plant regulator controlling development of symbiotic root nodules. Nature 402:191-195.

Schenk, S. T., Hernandez-Reyes, C., Samans, B., Stein, E., Neumann, C., Schikora, M., Reichelt, M., Mithofer, A., Becker, A., Kogel, K. H., and Schikora, A. 2014. N-acyl-homoserine lactone primes plants for cell wall reinforcement and induces resistance to bacterial pathogens via the salicylic acid/oxylipin pathway. Plant Cell 26: 2708-2723.

Schiessl, K., Lilley, J. L. S., Lee, T., Tamvakis, I., Kohlen, W., Bailey, P. C., Thomas, A., Luptak, J., Ramakrishnan, K., Carpenter, M. D., Mysore, K. S., Wen, J., Ahnert, S., Grieneisen, V. A., and Oldroyd, G. E. D. 2019. NODULE INCEPTION recruits the lateral root developmental program for symbiotic nodule organogenesis in Medicago truncatula. Curr. Biol. 29:3668.e5

Schikora, A., Schenk, S. T., Stein, E., Molitor, A., Zuccaro, A., and Kogel, K. H. 2011. N-acyl-homoserine lactone confers resistance toward biotrophic and hemibiotrophic pathogens via altered activation of AtMPK6. Plant Physiol. 157:1407-1418.

Schnabel, E., Journet, E. P., de Carvalho-Niebel, F., Duc, G., and Frugoli, J. 2005. The Medicago truncatula SUNN gene encodes a CLV1-like leucine-rich repeat receptor kinase that regulates nodule number and root length. Plant Mol. Biol. 58:809-822.

Searle, I. R., Men, A. E., Laniya, T. S., Buzas, D. M., Iturbe-Ormaetxe, I., Carroll, B. J., and Gresshoff, P. M. 2003. Long-distance signaling in nodulation directed by a CLAVATA1-like receptor kinase. Science 299: 109-112.

Sharma, N. K., and Sethi, C. L. 1976. Interrelationship between Meloidogyne incognita, Heterodera cajani and Rhizobium sp. on cowpea (Vigna sinensis (L.) Savi). Indian J. Nematol. 6:117-123.

Sharma, R. K., and Tiagi, B. 1990. Effect of Meloidogyne incognita on nodulation and symbiotic nitrogen fixation in pea. Nematol. Mediterr. 18:15-17.
Shaw, S. L., and Long, S. R. 2003. Nod factor inhibition of reactive oxygen efflux in a host legume. Plant Physiol. 132:2196-2204.

Siddiqui, Z. A., and Akhtar, M. S. 2009. Effect of plant growth promoting rhizobacteria, nematode parasitic fungi and root-nodule bacterium on root-knot nematodes Meloidogyne javanica and growth of chickpea. Biocontrol Sci. Technol. 19:511-521.

Siddiqui, Z. A., Baghel, G., and Akhtar, M. S. 2007. Biocontrol of Meloidogyne javanica by Rhizobium and plant growth-promoting rhizobacteria on lentil. World J. Microbiol. Biotechnol. 23:435-441.

Siddiqui, Z. A., Fatima, M., and Alam, S. 2013. Interactions of Meloidogyne incognita, Xanthomonas campestris, and Rhizobium sp. in the disease complex of chickpea. Turk. J. Agric. For. 37:173-178.

Siddiqui, Z. A., and Husain, S. I. 1992. Interaction between Meloidogyne incognita race 3, Macrophomina phaseolina and Bradyrhizobium sp. in the root-rot disease complex of chickpea, Cicer arietinum. Fundam. Appl. Nematol. 15:491-494.

Siddiqui, Z. A., and Mahmood, I. 2001. Effects of rhizobacteria and root symbionts on the reproduction of Meloidogyne javanica and growth of chickpea. Bioresour. Technol. 79:41-45.

Siddiqui, Z. A., Mir, R. A., and Mahmood, I. 1999. Effects of Meloidogyne incognita, Fusarium oxysporum $\mathrm{f}$. sp. pisi, Rhizobium sp., and different soil types on growth, chlorophyll, and carotenoid pigments of pea. Isr. J. Plant Sci. 47:251-256.

Sikder, M. M., and Vestergård, M. 2020. Impacts of root metabolites on soil nematodes. Front. Plant Sci. 10:1792.

Soyano, T., Shimoda, Y., Kawaguchi, M., and Hayashi, M. 2019. A shared gene drives lateral root development and root nodule symbiosis pathways in Lotus. Science 366:1021-1023.

Sprent, J. I. 2007. Evolving ideas of legume evolution and diversity: A taxonomic perspective on the occurrence of nodulation. New Phytol. 174:11-25.

Sprent, J. I., and James, E. K. 2007. Legume evolution: Where do nodules and mycorrhizas fit in? Plant Physiol. 144:575-581.

Staehelin, C., and Krishnan, H. B. 2015. Nodulation outer proteins: Doubleedged swords of symbiotic rhizobia. Biochem. J. 470:263-274.

Streeter J. 1988. Inhibition of legume nodule formation and $\mathrm{N}_{2}$ fixation by nitrate. Crit. Rev. Plant Sci. 7:1-23.

Streeter, J. G. 1994. Failure of inoculant rhizobia to overcome the dominance of indigenous strains for nodule formation. Can. J. Microbiol. 40:513-522.

Sugiyama, A., Saida, Y., Yoshimizu, M., Takanashi, K., Sosso, D., Frommer, W. B., and Yazaki, K. 2017. Molecular characterization of LjSWEET3, a sugar transporter in nodules of Lotus japonicus. Plant Cell Physiol. 58:298-306.

Sun, J., Cardoza, V., Mitchell, D. M., Bright, L., Oldroyd, G., and Harris, J. M. 2006. Crosstalk between jasmonic acid, ethylene and Nod factor signaling allows integration of diverse inputs for regulation of nodulation. Plant $\mathbf{J}$. 46:961-970.

Taha, A. H. Y., and Kassab, A. S. 1980. Interrelations between Meloidogyne javanica, Rotylenchus reniformis, and Rhizobium sp. on Vigna sinensis. J. Nematol. 12:57-62.

Taha, A. H. Y., and Raski, D. J. 1969. Interrelationships between rootnodule bacteria, plant-parasitic nematodes and their leguminous host. J. Nematol. 1:201-211.

Teixeira, M. A., Wei, L., and Kaloshian, I. 2016. Root-knot nematodes induce pattern-triggered immunity in Arabidopsis thaliana roots. New Phytol. 211:276-287.

Tellström, V., Usadel, B., Thimm, O., Stitt, M., Küster, H., and Niehaus, K. 2007. The lipopolysaccharide of Sinorhizobium meliloti suppresses defense-associated gene expression in cell cultures of the host plant Medicago truncatula. Plant Physiol. 143:825-837.

Teplitski, M., Mathesius, U., and Rumbaugh, K. P. 2011. Perception and degradation of $\mathrm{N}$-acyl homoserine lactone quorum sensing signals by mammalian and plant cells. Chem. Rev. 111:100-116.

Tirichine, L., Sandal, N., Madsen, L. H., Radutoiu, S., Albrektsen, A. S., Sato, S., Asamizu, E., Tabata, S., and Stougaard, J. 2007. A gain-offunction mutation in a cytokinin receptor triggers spontaneous root nodule organogenesis. Science 315:104-107.

Topalović, O., Bredenbruch, S., Schleker, A. S. S., and Heuer, H. 2020 Microbes attaching to endoparasitic phytonematodes in soil trigger plant defense upon root penetration by the nematode. Front. Plant Sci. 11:138

Tóth, K., and Stacey, G. 2015. Does plant immunity play a critical role during initiation of the legume-rhizobium symbiosis? Front. Plant Sci. 6:401.

Truong, N. M., Nguyen, C.-N., Abad, P., Quentin, M., and Favery, B. 2015. Function of root-knot nematode effectors and their targets in plant parasitism. Adv. Bot. Res. 73:293-324.

Tsai, A. Y., Oota, M., and Sawa, S. 2020. Chemotactic host-finding strategies of plant endoparasites and endophytes. Front. Plant Sci. 11: 1167. 
Udvardi, M., and Poole, P. S. 2013. Transport and metabolism in legumerhizobia symbioses. Annu. Rev. Plant Biol. 64:781-805.

Van de Velde, W., Zehirov, G., Szatmari, A., Debreczeny, M., Ishihara, H., Kevei, Z., Farkas, A., Mikulass, K., Nagy, A., Tiricz, H., SatiatJeunemaître, B., Alunni, B., Bourge, M., Kucho, K., Abe, M., Kereszt, A., Maroti, G., Uchiumi, T., Kondorosi, E., and Mergaert, P. 2010. Plant peptides govern terminal differentiation of bacteria in symbiosis. Science 327:1122-1126.

van Spronsen, P. C., Bakhuizen, R., van Brussel, A. A., and Kijne, J. W. 1994. Cell wall degradation during infection thread formation by the root nodule bacterium Rhizobium leguminosarum is a two-step process. Eur. J. Cell Biol. 64:88-94.

van Velzen, R., Doyle, J. J., and Geurts, R. 2019. A resurrected scenario: Single gain and massive loss of nitrogen-fixing nodulation. Trends Plant Sci. 24:49-57.

Vance, C. P., and Reichel, G. H. 1991. Carbon in $\mathrm{N}_{2}$ fixation: Limitation of exquisite adaptation. Annu. Rev. Plant Physiol. Plant Mol. Biol. 42: 373-392.

Veliz-Vallejos, D. F., Kawasaki, A., and Mathesius, U. 2020. The presence of plant-associated bacteria alters responses to $\mathrm{N}$-acyl homoserine lactone quorum sensing signals that modulate nodulation in Medicago truncatula. Plants 9:777.

Veliz-Vallejos, D. F., van Noorden, G. E., Yuan, M., and Mathesius, U. 2014. A Sinorhizobium meliloti-specific N-acyl homoserine lactone quorum-sensing signal increases nodule numbers in Medicago truncatula independent of autoregulation. Front. Plant Sci. 5:551.

Verdejo-Lucas, S., Cortada, L., Sorribas, F. J., and Ornat, C. 2009. Selection of virulent populations of Meloidogyne javanica by repeated cultivation of $M i$ resistance gene tomato rootstock under field conditions. Plant Pathol. 58:990-998.

Vinardell, J. M., Fedorova, E., Cebolla, A., Kevei, Z., Horvath, G., Kelemen, Z., Tarayre, S., Roudier, F., Mergaert, P., Kondorosi, A., and Kondorosi, E. 2003. Endoreduplication mediated by the anaphasepromoting complex activator CCS52A is required for symbiotic cell differentiation in Medicago truncatula nodules. Plant Cell 15: 2093-2105.

von Reuss, S. H. 2018. Exploring modular glycolipids involved in nematode chemical communication. Chimia (Aarau) 72:297-303.

von Reuss, S. H., Bose, N., Srinivasan, J., Yim, J. J., Judkins, J. C., Sternberg, P. W., and Schroeder, F. C. 2012. Comparative metabolomics reveals biogenesis of ascarosides, a modular library of small-molecule signals in C. elegans. J. Am. Chem. Soc. 134:1817-1824.

Vovlas, N., Vovlas, A., Leonetti, P., Liébanas, G., Castillo, P., Subbotin, S. A., and Palomares Rius, J. E. 2015. Parasitism effects on white clover by root-knot and cyst nematodes and molecular separation of Heterodera daverti from H. trifolii. Eur. J. Plant Pathol. 143:833-845.

Wasson, A. P., Pellerone, F. I., and Mathesius, U. 2006. Silencing the flavonoid pathway in Medicago truncatula inhibits root nodule formation and prevents auxin transport regulation by rhizobia. Plant Cell 18:1617-1629.

Wasson, A. P., Ramsay, K., Jones, M. G. K., and Mathesius, U. 2009. Differing requirements for flavonoids during the formation of lateral roots, nodules and root knot nematode galls in Medicago truncatula. New Phytol. 183:167-179.
Weerasinghe, R. R., Bird, D. M., and Allen, N. S. 2005. Root-knot nematodes and bacterial Nod factors elicit common signal transduction events in Lotus japonicus. Proc. Natl. Acad. Sci. U.S.A. 102:3147-3152.

Wei, L., Shao, Y., Wan, J., Feng, H., Zhu, H., Huang, H., and Zhou, Y. 2014. Isolation and characterization of a rhizobacterial antagonist of root-knot nematodes. PLoS One 9:e85988.

Williamson, V. M., and Gleason, C. A. 2003. Plant-nematode interactions. Curr. Opin. Plant Biol. 6:327-333.

Wood, C. W., Pilkington, B. L., Vaidya, P., Biel, C., and Stinchcombe, J. R. 2018. Genetic conflict with a parasitic nematode disrupts the legumerhizobia mutualism. Evol. Lett. 2:233-245.

Wuyts, N., Lognay, G., Swennen, R., and De Waele, D. 2006a. Nematode infection and reproduction in transgenic and mutant Arabidopsis and tobacco with an altered phenylpropanoid metabolism. J. Exp. Bot. 57: 2825-2835.

Wuyts, N., Swennen, R., and De Waele, D. 2006b. Effects of plant phenylpropanoid pathway products and selected terpenoids and alkaloids on the behaviour of the plant-parasitic nematodes Radopholus similis, Pratylenchus penetrans and Meloidogyne incognita. Nematol. 8: 89-101.

Xiao, T. T., Schilderink, S., Moling, S., Deinum, E. E., Kondorosi, E., Franssen, H., Kulikova, O., Niebel, A., and Bisseling, T. 2014. Fate map of Medicago truncatula root nodules. Dev. 141:3517-3528.

Zdyb, A., Demchenko, K., Heumann, J., Mrosk, C., Grzeganek, P., Göbel, C., Feussner, I., Pawlowski, K., and Hause, B. 2011. Jasmonate biosynthesis in legume and actinorhizal nodules. New Phytol. 189:568-579.

Zgadzaj, R., Garrido-Oter, R., Jensen, D. B., Koprivova, A., SchulzeLefert, P., and Radutoiu, S. 2016. Root nodule symbiosis in Lotus japonicus drives the establishment of distinctive rhizosphere, root, and nodule bacterial communities. Proc. Natl. Acad. Sci. U.S.A. 113: E7996-E8005.

Zhang, J., Subramanian, S., Stacey, G., and Yu, O. 2009. Flavones and flavonols play distinct critical roles during nodulation of Medicago truncatula by Sinorhizobium meliloti. Plant J. 57:171-183.

Zhang, X., Li, K., Jones, R. A., Bruner, S. D., and Butcher, R. A. 2016. Structural characterization of acyl-CoA oxidases reveals a direct link between pheromone biosynthesis and metabolic state in Caenorhabditis elegans. Proc. Natl. Acad. Sci. U.S.A. 113:10055-10060.

Zhao, J., Li, L., Liu, Q., Liu, P., Li, S., Yang, D., Chen, Y., Pagnotta, S., Favery, B., Abad, P., and Jian, H. 2019. A MIF-like effector suppresses plant immunity and facilitates nematode parasitism by interacting with plant annexins. J. Exp. Bot. 70:5943-5958.

Zhou, Y., Wang, Y., Zhang, X., Bhar, S., Jones Lipinski, R. A., Han, J., Feng, L., and Butcher, R. A. 2018. Biosynthetic tailoring of existing ascaroside pheromones alters their biological function in C. elegans. eLife 7:e33286.

Zimmer, S., Messmer, M., Haase, T., Piepho, H. P., Mindermann, A., Schulz, H., Habekuß, A., Ordon, F., Wilbois, K. P., and Heß, J. 2016. Effects of soybean variety and Bradyrhizobium strains on yield, protein content and biological nitrogen fixation under cool growing conditions in Germany. Eur. J. Agron. 72:38-46.

Zipfel, C., and Oldroyd, G. E. 2017. Plant signalling in symbiosis and immunity. Nature 543:328-336. 